\title{
Os mercados de escravos africanos recém-chegados às Américas: padrões de preços, 1673-1865*
}

\author{
David Eltis e David Richardson
}

Os preços dos escravos têm importância crucial para a compreensão não só do tráfico negreiro, mas também, em uma escala mais ampla, da economia atlântica nos dois séculos após 1660. Nos últimos 30 anos, uma gama de fontes vem fornecendo dados relativos ao século dezenove sobre venda de escravos nos EUA, Cuba e Brasil. Mesmo que o status dos escravos dos quais derivam estes dados tenha variado quase tanto quanto a sua localização geográfica, os padrões de preços que eles revelam têm demonstrado semelhanças notáveis. ${ }^{1}$ Excetuando, no Brasil, Minas Gerais e talvez a Bahia, o período pré-1800 é muito subestimado. Ademais, mesmo para o século dezenove, os dados advêm da venda de indivíduos que já moravam nas América há algum tempo. O único corpus substancial de dados sobre Africanos recém-chegados, e até mesmo sobre o período pré-1800, é o da ilha de Barbados entre 1673 e $1723 .^{2}$ Porém, os trabalhos recentes sobre a remessa de escravos da África para as Américas, os quais culminaram com a publicação do CD ROM da Cambridge University Press ${ }^{3}$ sobre o comércio de escravos, redundaram em um corpus substancial de novos dados sobre preços. Estes cobrem não somente uma vasta gama de regiōes nas Américas, mas também o período no qual o comércio de escravos cresceu desde os modestos índices dos idos do século dezessete até seu ápice no final do século dezoito, seguindo-se então o início de seu lento declínio. Como foi também possível incorporar à análise dados sobre preços de escravos pós-1808, pudemos oferecer uma imagem razoavelmente completa

* Tradução de Aline Lorena Tolosa. Revisão técnica de Manolo Florentino. 
da ascensão e queda do tráfico, a qual amplia e possui vantagens evidentes sobre o trabalho de Richard Bean, feito trinta anos atrás. ${ }^{4}$ Como mostra a tabela 1, parece agora razoável afirmar que não menos do que 92 por cento de todos os escravos trazidos através do Atlântico viajaram durante o período para o qual dados razoavelmente confiáveis de preços estão disponíveis.

\section{Tabela 1 - Volume de partidas transatlânticas de escravos por região africana e por periodo de anos, 1519-1867 (em milhares)}

\begin{tabular}{|c|c|c|c|c|c|c|c|c|c|}
\hline & $\begin{array}{c}\text { Sene- } \\
\text { gambia }\end{array}$ & $\begin{array}{c}\text { Serra } \\
\text { Leoa }\end{array}$ & $\begin{array}{c}\text { Windward } \\
\text { Coast }\end{array}$ & $\begin{array}{c}\text { Costa } \\
\text { do Ouro }\end{array}$ & $\begin{array}{c}\text { Baía de } \\
\text { Benin }\end{array}$ & $\begin{array}{c}\text { Baía de } \\
\text { Biafra }\end{array}$ & $\begin{array}{c}\text { Africa } \\
\text { Central } \\
\text { Atlântica }\end{array}$ & $\begin{array}{c}\text { Africa } \\
\text { Oriental } \\
\text { e do Sul }\end{array}$ & $\begin{array}{c}\text { Todas as } \\
\text { regióes }\end{array}$ \\
\hline $1519-1600$ & 10.7 & 2 & 0 & 10.7 & 10.7 & 10.7 & 221.2 & 0 & 266.1 \\
$1601-1650$ & 6.4 & 0 & 0 & 5.2 & 2.4 & 25.5 & 461.9 & 2 & 503.5 \\
$1651-1675$ & 17.7 & 0.4 & 0.1 & 35.4 & 21.9 & 58.6 & 104.3 & 1.2 & 239.8 \\
$1676-1700$ & 36.5 & 3.5 & 0.7 & 50.3 & 223.5 & 51.5 & 132.6 & 10.9 & 509.5 \\
$1701-1725$ & 39.9 & 7.1 & 4.2 & 181.7 & 408.3 & 45.8 & 257.2 & 14.4 & 958.6 \\
$1726-1750$ & 69.9 & 10.5 & 14.3 & 186.3 & 306.5 & 166 & 552.8 & 5.4 & 1311.3 \\
$1751-1775$ & 130.4 & 96.9 & 105.1 & 263.9 & 250.5 & 340.1 & 714.9 & 3.3 & 1905.2 \\
$1776-1800$ & 72.4 & 106 & 19.5 & 240.7 & 264.6 & 3604 & 816.2 & 41.2 & 1921.1 \\
$1801-1825$ & 91.7 & 69.7 & 24 & 69 & 263.3 & 260.3 & 700.8 & 131.8 & 1610.6 \\
$1826-1850$ & 22.8 & 100.4 & 14.4 & 0 & 257.3 & 191.5 & 770.6 & 247.5 & 1604.5 \\
$1851-1867$ & 0 & 16.1 & 0.6 & 0 & 25.9 & 7.3 & 155 & 26.8 & 231.7 \\
Todos os anos & 498.5 & 412.7 & 183 & 1043.2 & 2034.6 & 1517.9 & 4887.5 & 484.5 & 11062 \\
\% do tráfico & 4.5 & 3.7 & 1.7 & 9.4 & 18.4 & 13.7 & 44.2 & 4.4 & 100 \\
\hline
\end{tabular}

Fonte: David Eltis, "The Volume and Structure of the Transatlantic Slave Trade: A Reassessment", in: William and Mary Quarterly (2001)

\section{II}

As séries de preços de escravos aqui apresentadas baseiam-se em grande parte em dados primários, publicados e inéditos, associados aos preços de 242,274 africanos escravizados trazidos para as Américas por meio de 1.056 viagens transatlânticas entre 1673 e 1808. A base de dados inclui algumas viagens à América espanhola continental, porém a grande maio- 
ria diz respeito às Índias Ocidentais (incluindo o Suriname e Demerara) e à América britânica continental. Estes dados derivam de fontes sobre o comércio de escravos inglês, holandês, francês e do continente norte-americano. Aproximadamente dois terços destas viagens eram inglesas; a maior parte do restante era ou francesa ou holandesa. O nome do navio em questão é conhecido em aproximadamente 91 por cento das viagens; a maioria dos navios desconhecidos é provavelmente inglesa. Na medida em que se conhece o nome destes navios, os dados sobre preços contidos nesta série podem ser associados, em sua maioria, diretamente ao conjunto mais amplo de dados sobre 27,233 viagens transatlânticas de negreiros contida no CD ROM da Cambridge. Uma base de dados suplementar abrange dados sobre 40.000 escravos homens nascidos na África, com idades entre 15 e 40 anos, vendidos em Cuba entre 1796 e 1867. Após os ajustes necessários, estes dados podem ser usados para ampliar a série até o término do comércio transatlântico de escravos. ${ }^{5}$

Ao calcular a série de preços, usamos evidências empíricas sobre preços médios de escravos compilados das vendas de carregamentos de cativos ou de relatos coevos. Quando possível, usamos dados de preços para carregamentos inteiros de escravos, porém algumas vezes isto acarretou a segmentação das 'cargas humanas' em grupos menores, vendidos em diferentes mercados. O número médio de escravos por carga de navio (baseado em 885 viagens) foi de 229; este número foi usado para calcular o número total de escravos coberto pela amostra da viagem inteira. Não adotamos nenhum número arbitrário para as cargas com o intuito de incluir dados sobre preços na série, embora tenhamos voluntariamente tentado evitar a dependência de grupos muito pequenos ou de carregamentos parciais de escravos. $\mathrm{O}$ maior grupo de escravos vendidos por um navio dentro da série é de 764; o menor, de 13. Porém, apenas 25 carregamentos ou grupos contavam com menos do que 50 escravos. Os dados brutos contidos na série de preços estão, portanto, majoritariamente relacionados aos preços médios de carregamentos com um total de 50 ou mais africanos escravizados. Alguns carregamentos completos - especialmente no caso de navios norte-americanos - eram muito pequenos. Ademais, não foram incluídos carregamentos parciais que se compunham claramente de grupos de escravos doentes vendidos ao final de um pregão. 
Os registros de preços de escravos eram às vezes realizados em moeda européia, noutras em moedas coloniais e, ainda, nos dois, o que permite calcular a taxa de câmbio entre ambas as moedas. Procuramos padronizar todos os preços em libras esterlinas, utilizando para tal as taxas de câmbio contidas nos relatos ou obtidas de outras fontes, tais como o compêndio de McCusker sobre taxas cambiais. ${ }^{6}$ Não podemos garantir sucesso absoluto em decifrar os câmbios europeus e coloniais. Como estes últimos, porém, se depreciavam consideravelmente em vista de seu congênere europeu, estamos confiantes de haver identificado a grande maioria dos casos nos quais os relatos foram feitos em moedas coloniais, fazendo, portanto, os ajustes necessários.

A série de preços que apresentamos está associada aos preços pagos na Jamaica, à vista e em libras esterlinas, por homens escravizados em idade mais produtiva (padrão). A Jamaica foi o principal local de desembarque de africanos escravizados na América Britânica no período 1673-1808. Os preços estão apresentados primeiramente em valores correntes, e depois em libras constantes. A construção desta série envolveu algumas correções nos dados originais de preços. Especificamente, procedeu-se

(a) ao ajuste ou o desconto de preços em operaçóes a crédito de modo a incorporar as mudanças nas condições de crédito na compra de escravos;

(b) à conversão dos preços médios à vista de grupos de escravos ao seu equivalente para escravos-padrão;

(c) à padronização dos preços de escravos em diferentes mercados na América para o seu equivalente jamaicano.

No caso (a), os preços foram corrigidos com o intuito de abranger os termos em que as operações a crédito eram relatadas, assumindo qual era o período apropriado quando este dado não era fornecido pelas fontes. Para efeito de desconto, assumimos que as taxas de juros eram de 10 por cento ao ano antes de 1697, de 7 por cento nos anos de paz entre 1697-1701, de 8 por cento nos anos de guerra de 1702 a 1713, e daí em diante de 5 por cento nas épocas de paz e de 6 por cento nos períodos de guerra. Para converter os preços à vista de grupos de escravos em seu equivalente padrão seguimos Galenson, usando o preço médio de homens adultos vendidos 
no primeiro terço das vendas de um carregamento de escravos em relação ao preço médio do carregamento como um todo. ${ }^{7}$ Baseado na análise dos preços de 73 carregamentos de escravos entre 1670 e 1800, a razão entre preços para homens-padrão e o preço médio da 'carga' era de 1.3063 (STD 0.1585). Os preços médios à vista foram, portanto, acrescidos em 31 por cento para estimar o equivalente-padrão. Finalmente, para a conversão dos preços de escravos de uma diversidade de mercados para os seus equivalentes jamaicanos, usamos dados sobre os custos de transporte para delimitar três zonas de mercados de escravos. Estas são (1) Caribe leste (incluindo Barbados, Pequenas Antilhas, o Suriname, Demerara e Buenos Aires); (2) Caribe Oeste (Cuba, Jamaica e São Domingos) e (3) Estados Unidos. Para padronizar os preços para a Jamaica, os valores dos escravos vendidos na zona (1) foram inflacionados em 6 por cento (10 por cento antes de 1691) e os da zona (2) foram reduzidos em 5 por cento para acomodar as diferenças nos preços de transporte entre mercados. ${ }^{8}$ Para o período pré-1690, ajustes adicionais foram feitos para abranger o fato de que a pirataria e a instabilidade generalizada do oeste do Caribe no século dezessete aumentavam os riscos para embarcações que se dirigiam a esta região. ${ }^{9}$ Da mesma forma, para estimar os equivalentes jamaicanos, multiplicamos os preços de escravos da zona (1) por 1.10 para o período pré-1691 e por 1.06 daí em diante, e os da zona (3) por 0.95. Não foram feitos ajustes nos preços dos escravos vendidos fora da Jamaica em regiōes inclusas na zona (2).

Para o período pós-1807 (na verdade, pós-1805) decidimo-nos pelo uso de registros individuais de homens escravos identificados como africanos, entre as idades de 15 e 40 anos, vendidos em Cuba até 1865. A maioria desses indivíduos já deveria estar em Cuba a algum tempo antes da venda, ou seja, já teriam passado pelo período de elevada mortalidade comumente associado com a chegada às Américas em navios negreiros (o chamado "seasoning"), obtendo portanto preços mais altos do que os "boçais" ou escravos recém-chegados que perfazem a amostragem pré-1808. Portanto, para compatibilizar as observaçôes pré e pós-1808, os preços dos escravos cubanos foram deflacionados em dez por cento. ${ }^{10}$ A despeito destes ajustes, no entanto, as duas bases de dados não são facilmente comparáveis. Antes de 1808 os preços resultam essencialmente de médias calculadas a partir do valor total do carregamento completo de escravos, ajustadas 
para a obtenção de preços de homens-padrão — em outras palavras, a unidade básica é o número total de escravos a bordo ao desembarcarem na América. Após 1807, a unidade dos dados é o escravo individual. Mesmo assim, os dois tipos de dados podem ser combinados para estabelecermos um padrão, e podem ser feitas comparações seccionais se forem tratadas como séries separadas.

\section{III}

Uma análise de preços deve ser feita tendo em conta o pano de fundo do que conhecemos da estrutura do comércio de escravos. Este perfil é mostrado na figura 1, bem como nas tabelas 1 e 2 . Mesmo tendo a primeira viagem transatlântica de escravos provavelmente aportado em 1519, o primeiro século e meio de tráfico direto viu provavelmente um total de menos de um milhão de escravos (ou aproximadamente 8 por cento do tráfico agregado) deixar a África. A grande maioria destas primeiras vítimas do comércio negreiro foi levada da África Central Atlântica para o Brasil. A intensificação crescente da quantidade de carregamentos de escravos durante a segunda metade do século dezessete foi seguida por aumentos substanciais na centúria seguinte. No todo, aproximadamente 85 por cento dos escravos africanos atravessaram o Atlântico entre 1700 e 1850. Nesse período de intenso comércio houve enormes variações por qüinqüênio, impostas pela guerra generalizada no Atlântico, representada pelas flutuações da figura $1 .{ }^{11}$ No lado africano, durante um século no início e durante um quarto de século ao final do período do comércio negreiro, a África Central Atlântica remeteu mais escravos que todas as outra regióes combinadas, e entre 1800 e 1850 chegou novamente perto desta marca. Todas as regiões da África experimentaram um único e evidente movimento ascendente nas quantidades de pessoas remetidas ao tráfico. ${ }^{12}$ A África Central Atlântica foi a primeira região a passar por este grande movimento ascendente, provavelmente pelo final do século dezesseis, quando o comércio de escravos para o Brasil e para a América espanhola tornou-se substancial. A escravatura em seu início espalhou-se lentamente pelas Américas, e foi apenas um século depois que a expansão da produção de açúcar, especialmente no Caribe inglês, incorporou a baía de Benin à órbi- 
ta do comércio de escravos. O prosseguimento da expansão, desta vez tanto no Caribe quanto no Brasil, trouxe a Costa do Ouro para dentro da turbulência pós-1700, seguida pela baía de Biafra após 1725, as três regióes da Alta Guiné, juntas, após 1750 e, por último, enquanto desenrolavamse os ciclos de açúcar e café brasileiros, a África sul-oriental no final do século dezoito. Após a onda inicial, a maioria dessas regiōes manteve níveis elevados de partidas durante um século ou mais. A exceção a este padrão foi a Alta Guiné - a costa barlavento manteve-se nestes patamares elevados por apenas duas décadas, a Senegâmbia por um período um pouco maior e Serra Leoa por meio século. Excetuando o terceiro quarto do século dezoito, as exportações destas três regiōes combinadas não conseguiram, antes de 1800, equiparar-se ao volume de escravos que deixavam qualquer uma das outras cinco regiões, devendo ser consideradas fornecedores menores de escravos para a América durante a maioria dos períodos.

\section{Tabela 2 - Volume de escravos africanos desembarcados por região de chegada nas Américas e por período de anos, 1519-1867 (em milhares)}

\begin{tabular}{|l|c|c|c|c|c|c|c|c|}
\hline & $\begin{array}{c}\text { Estados } \\
\text { Unidos }\end{array}$ & $\begin{array}{c}\text { Ilhas } \\
\text { Leeward } \\
\text { inglesas }\end{array}$ & $\begin{array}{c}\text { Ilhas } \\
\text { Windward } \\
\text { e Trinidad }\end{array}$ & Jamaica & Barbados & Guianas & $\begin{array}{c}\text { Windward } \\
\text { francesas }\end{array}$ & $\begin{array}{c}\text { Saint } \\
\text { Domingue }\end{array}$ \\
\hline $1519-1600$ & 0 & 0 & 0 & 0 & 0 & 0 & 0 & 0 \\
$1601-1650$ & 0.8 & 1 & 0.2 & 0 & 22.4 & 0 & 1 & 0 \\
$1651-1675$ & 0.9 & 5.6 & 0 & 22.3 & 63.2 & 8.2 & 6.5 & 0 \\
$1676-1700$ & 9.8 & 26.6 & 0 & 73.5 & 82.3 & 27.8 & 16.6 & 4.8 \\
$1701-1725$ & 37.4 & 35.4 & 0.6 & 139.1 & 91.8 & 24.4 & 30.1 & 44.5 \\
$1726-1750$ & 96.8 & 81.7 & 0.3 & 186.5 & 73.6 & 83.6 & 66.8 & 144.9 \\
$1751-1775$ & 116.9 & 123.9 & 120 & 270.4 & 120.9 & 111.9 & 63.7 & 247.5 \\
$1776-1800$ & 24.4 & 25.3 & 197.5 & 312.6 & 28.5 & 71.2 & 41.2 & 345.8 \\
$1801-1825$ & 73.1 & 5.3 & 43 & 70.2 & 7.6 & 71.8 & 58.8 & 0 \\
$1826-1850$ & 0 & 0 & 0.5 & 2.1 & 0.9 & 4.8 & 19.5 & 0 \\
$1851-1867$ & 0.3 & 0 & 0 & 0.4 & 0 & 0 & 0 & 0 \\
Todos os anos & 360.4 & 304.2 & 362 & 1077.1 & 491.2 & 403.7 & 304.2 & 787.4 \\
\% do tráfico & 3.7 & 3.2 & 3.7 & 11.2 & 5.1 & 4.2 & 3.1 & 8.2 \\
\hline
\end{tabular}


Tabela 2 (cont.)

\begin{tabular}{|c|c|c|c|c|c|c|c|c|c|}
\hline & $\begin{array}{c}\text { América } \\
\text { Espanhola }\end{array}$ & $\begin{array}{c}\text { Caribe } \\
\text { espanhol }\end{array}$ & $\begin{array}{c}\text { Caribe } \\
\text { holandês }\end{array}$ & $\begin{array}{c}\text { Nordeste } \\
\text { do Brasil }\end{array}$ & Bahia & $\begin{array}{c}\text { Sudeste } \\
\text { do Brasil }\end{array}$ & $\begin{array}{c}\text { Outras } \\
\text { regiōes } \\
\text { americanas }\end{array}$ & $\begin{array}{c}\text { África } \\
\text { Todas as } \\
\text { regiōes }\end{array}$ \\
\hline $1519-1600$ & 151.6 & 0 & 0 & 35 & 15 & 0 & 0 & 0 & 201.6 \\
$1651-1650$ & 187.7 & 0 & 1 & 86.3 & 60 & 30 & 0.6 & 0 & 390.4 \\
$1676-17075$ & 0 & 0 & 38.8 & 15.6 & 15.6 & 15.6 & 11 & 0 & 192.8 \\
$1701-1725$ & 6.9 & 0 & 26 & 56.1 & 104 & 54.5 & 14.2 & 0 & 500 \\
$1726-1750$ & 12.7 & 1.6 & 10.2 & 51.4 & 104.6 & 213.9 & 13.8 & 0 & 1136.9 \\
$1751-1775$ & 5 & 13 & 15.3 & 126.9 & 94.4 & 210.4 & 44.1 & 0.4 & 1653.9 \\
$1776-1800$ & 10.2 & 56.9 & 6.9 & 210.8 & 112.5 & 247.2 & 14.1 & 22.7 & 1735.4 \\
$1801-1825$ & 17.4 & 268.7 & 0 & 212.5 & 182 & 408.7 & 3.9 & 91.3 & 1455.9 \\
$1826-1850$ & 5.8 & 297 & 0 & 78.5 & 146.5 & 736.4 & 0.4 & 16.8 & 1387.2 \\
$1851-1867$ & 0 & 152.6 & 0 & 1.4 & 1.9 & 3.6 & 110.4 & 131.2 & 177.3 \\
Todos os anos & 427.2 & 791.9 & 128.7 & 8986.7 & 1036.1 & 2042.3 & 1.1 & 1.4 & 9657.1 \\
\% do tráfico & 4.4 & 8.2 & 1.3 & 9.3 & 10.7 & 21.1 & & & 100 \\
\hline
\end{tabular}

Fonte: a mesma da tabela 1

\section{Figura 1}

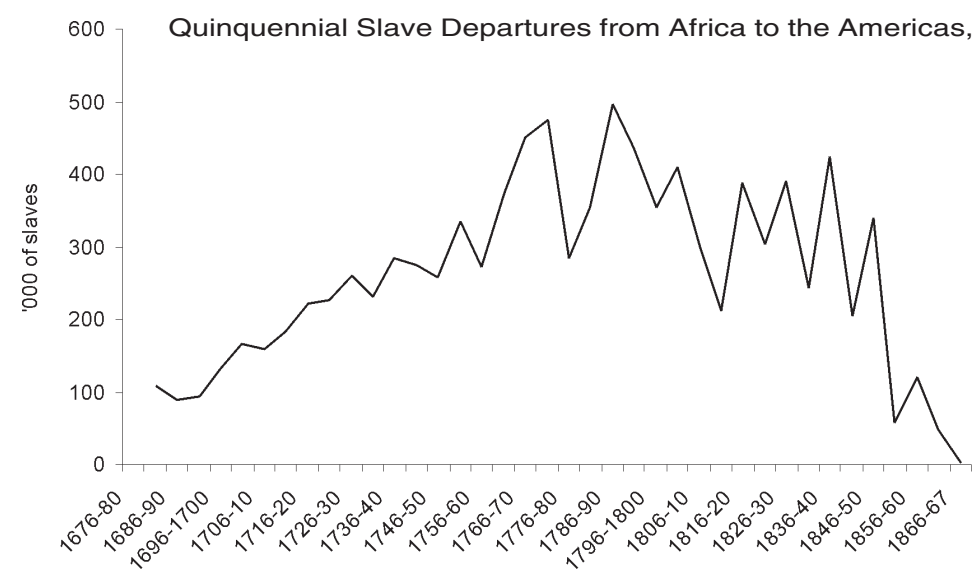

Fonte: David Eltis, Stephen D. Behrendt, David Richardson, e Herbert S. Klein, The Transatlantic Slave Trade: A Database on CD-ROM (Cambridge, 1999). 
Nas Américas, o domínio dos traficantes ingleses e portugueses era tal que não é surpreendente que o Brasil e a América britânica tenham recebido a maior quantidade de africanos — o Brasil com $41 \%$ dos escravos que chegavam ao Novo Mundo e a América britânica com 29\%. ${ }^{13}$ Assim, comparando ao movimento de escravos para outras regiōes, aproximadamente sete de cada dez escravos permanecia no Brasil ou na América britânica (apesar de os Estados Unidos provavelmente deterem uma quota maior do que a mostrada na tabela 2). A América francesa absorveu a metade dos escravos da América britânica, com Saint Domingue recebendo menos escravos que a Jamaica (mesmo após considerarmos o ajuste de carregamentos de traficantes espanhóis que ali desembarcaram). Na verdade, a América francesa recebeu menos escravos que qualquer outro grande império europeu nas Américas. A explicação disso é que Saint Domingue, que absorveu aproximadamente 80 por cento de todos os escravos que chegaram à América Francesa, foi uma colônia de plantations por um período relativamente curto de tempo. Insignificante no início e em ruínas ao fim do século dezoito, e geralmente do lado perdedor das guerras que atrapalhavam o tráfico de escravos, não obstante absorveu mais escravos que a Jamaica entre 1750 e 1791. Ademais, a América britânica era mais extensa em território e começou a receber grandes quantidades de escravos mais cedo que as ilhas francesas.

O comércio para as áreas continentais espanholas começou mais cedo do que em qualquer outro lugar e, através de Cuba, cresceu de modo explosivo, mesmo enquanto o comércio de escravos para o resto das Américas estava acabando. Como observou Fogel, escravos cruzaram o Atlântico principalmente para serem postos para trabalhar na produção de açúcar ou nas economias que a exportação de açúcar tornou possíveis. Tabaco, arroz, índigo e cacau eram setores secundários em termos globais, embora importantes localmente. A produção de ouro e prata no início da colonização espanhola, e em Minas Gerais depois de 1695, foi uma fonte importante de demanda. Mas enquanto a América espanhola dominou o incipiente comércio de escravos, o fluxo de africanos para esta área era pequeno quando comparado ao que se tornaria depois; e mesmo estando a descoberta de ouro em Minas Gerais relacionada à grande expansão do comércio brasileiro no início do século dezoito, muito mais escravos chega- 
ram ao Brasil após o boom do ouro - tanto no total como por ano. Além disso, tanto no Brasil quanto na América espanhola os picos demográficos estiveram mais associados à chegada de pessoas da Europa do que da África, ao passo que nas colônias açucareiras dos dois séculos após 1650 o aumento nas exportações de açúcar significava quase sempre um maior número de recém-chegados africanos que europeus. Do final do século dezesseis até 1820 , noventa por cento dos escravos trazidos através do Atlântico vieram por causa do açúcar, e a distribuição geográfica e temporal expressa na tabela 2 reflete essencialmente mudanças na economia açucareira.

\section{IV}

A partir deste pano de fundo pode-se agora voltar à série para um exame seccional dos novos dados obtidos. Um resumo descritivo dividido por qüinqüênios e por região africana de origem é apresentado no Apêndice 1 . O Apêndice 2 fornece um resumo semelhante para as regióes mais relevantes de chegada nas Américas para as quais os dados restaram. Conforme foi dito antes, os preços têm por padrão homens no auge da idade produtiva na Jamaica ou, mais amplamente, para mercados caribenhos ocidentais. Enquanto todos os preços do apêndice estão em valores nominais, as figuras 2(a) e 2(b) mostram o resultado do deflacionamento destes preços e do ajuste para um perfil de longo prazo em libras esterlinas constantes, sendo a figura 2(a) para as Américas como um todo antes de 1808, e a 2(b) para Cuba depois de 1805. Apresentamos duas figuras separadas porque, como explicamos acima, as bases de dados para estes dois períodos são diferentes. Cada coordenada na figura 2(a) representa o preço médio de um grupo de homens-padrão vendidos em uma remessa completa, enquanto na figura 2(b) cada coordenada representa um único escravo do sexo masculino entre as idades de 15 e 40 anos. Além disso, índices de preço britânicos diferentes são usados para deflacionar os preços correntes nos dois períodos. ${ }^{15} \mathrm{~A}$ linha de tendência apresentada em ambas as figuras de dispersão fornece o melhor ajuste. ${ }^{16} \mathrm{O}$ aumento ao longo de quase dois séculos de comércio de escravos é evidente, mas menos óbvia é a natureza acelerada desse aumento. Entre os idos de 1670 e 1805-7, os preços aumentaram continuadamente segundo uma taxa de 0,75 por cento por ano, 
sendo a maioria das variações importantes explicadas por guerras. Nos dados de Cuba pós-1805, a variação é muito maior do que em período anteriores para as Américas como um todo. A linha de tendência sugere, não obstante, que a taxa anual de aumento mais que dobrou no século dezenove, pulando para 1,7 por cento ao ano, mas, diferentemente do século anterior, a maior parte desse aumento concentrou-se no fim do período (veio depois de 1840).

Uma comparação da figura 1 com as figuras 2(a) e 2(b) mostra que a série temporal de preços de escravos não segue exatamente a mesma tendência do volume de escravos trazidos da África (ou vice-versa). Os preços nominais de escravos nas Américas e o volume de partidas de escravos cresceram continuamente no curso do último terço do século dezessete e ao longo do século dezoito, mas enquanto o número de escravos quadruplicou, seus preços aumentaram apenas para o dobro ou triplo neste período. Depois de 1800, porém, a direção das duas séries diverge. Os preços de escravos continuam a aumentar — desta vez mais fortemente do que no século dezoito - , mas o volume do tráfico de escravos diminuiu irregularmente a partir do fim dos anos 1790, tendendo a zero vindo após 1850 . Tal queda coincidiu, pois, com a subida de preços de escravos aos níveis provavelmente mais altos da história de escravidão em qualquer lugar do mundo, sem importar a forma de aferição. De outro modo, é possível observar um ajuste proporcional entre, de um lado, médias qüinqüenais do volume de escravos e, do outro, os preços dos escravos antes de 1800, sendo positivo o sinal do coeficiente de preços. Depois de 1800, preços e volume tendem a estar negativamente relacionados. De modo contrastante, nenhum resultado expressivo pode ser alcançado se ignorarmos a linha divisória representada por 1800 e os dados de modo agregado para todo o período 1673 a $1865 .{ }^{17}$ 
Figuras $2(A)$ e $2(B)$

Figure 2(A) - Prices of Newly Disembarked Prime Male Slaves In Western Caribbean Equivalences - 1673-1807, Constant Pounds

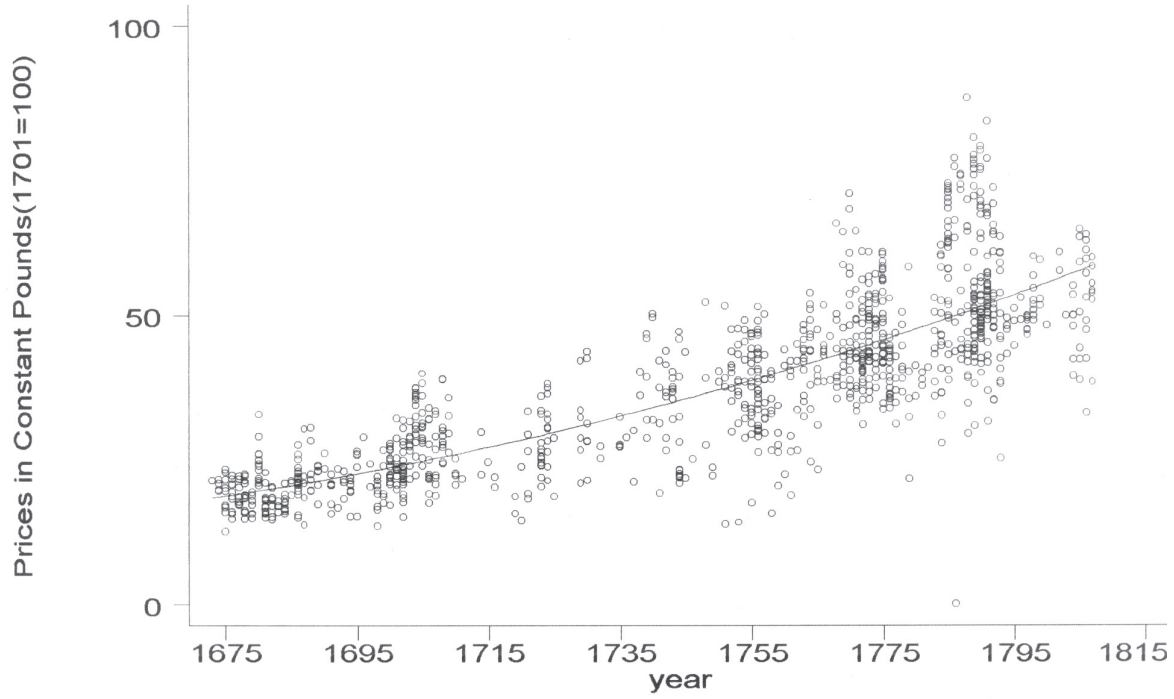

Figure 2(B) - Prices of Newly Disembarked Prime Male Slaves In Western Caribbean Equivalences - 1806-1865, Constant Pounds

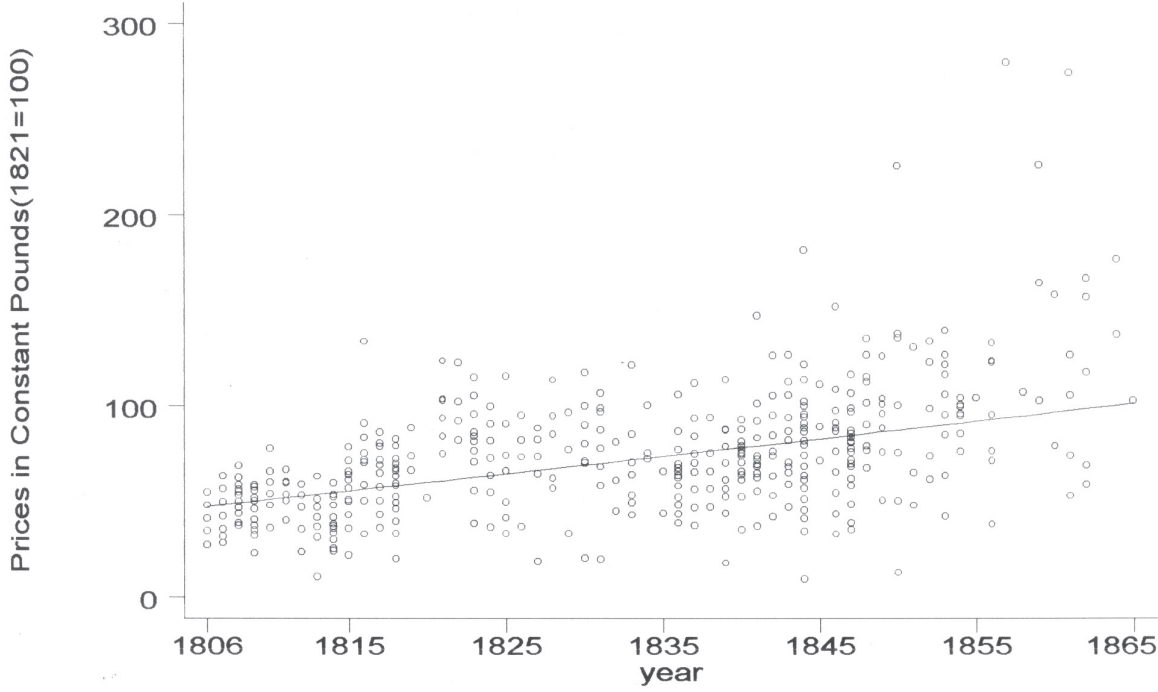


Os escravos produziram principalmente açúcar durante a era de comércio de escravos, como já referido antes. De que forma a produção de açúcar mudou com o passar do tempo? Os dados mais antigos sobre preços e produção são escassos, mas as estimativas apenas para o Caribe em três anos seminais - 1700, 1770 e 1850 — sugerem que o valor total de todas as colheitas quadruplicou ou quintuplicou entre os dois primeiros anos, aumentando entre duas e três vezes no período de 1770 a 1850 . O Caribe era flanqueado por um lado pelo sul dos EUA, onde a produção das plantations provavelmente cresceu mais rapidamente do que as Antilhas após 1800, e, ao sul, pelo Brasil, onde o crescimento da produção era um pouco mais lento, pelo menos até 1825 . Em outras palavras, se realmente, como parece provável, o Caribe representou a experiência média de toda a América escravocrata, o valor de produção dos escravos aumentou mais do que o volume de chegadas de africanos ou do que os preços de escravos para a maior parte do século dezoito; talvez ele tenha acompanhado os preços dos cativos no início do século dezenove, enquanto o volume de desembarques de escravos caiu. ${ }^{18}$ Uma interpretação desses padrões seculares é apresentada a seguir.

Variações de preços por região são de particular interesse devido ao largo alcance geográfico do comércio. Em um mercado perfeito, esperaríamos que as diferenças de preços entre as áreas de qualquer um dos lados do Atlântico refletissem diferenças de custos de transporte e da mortalidade a bordo. Nas Américas, nós agrupamos os preços em três grandes regiōes geográficas, o Caribe oriental, o Caribe ocidental e os Estados Unidos, e desenvolvemos uma série de preços corrigida de acordo com informações dos contemporâneos sobre o custo de transporte entre essas grandes regiões. Como referido acima, o resultado é uma série de preços padronizada tendo por base a Jamaica, mas para a análise seccional utilizamos os preços nominais em libra esterlina.

$\mathrm{Na}$ África, os dados sobre diferenciais de custo inter-regionais não são facilmente identificados, estando ademais marcados por sistemas de ventos e correntes complexos. Se definirmos o tempo de viagem de modo amplo, levando em conta o tempo decorrido entre a partida do porto natal do navio negreiro até o momento em que os escravos desembarcavam nas Américas, então a duração da viagem pode ser tomada como um subs- 
tituto para os custos. Em termos mais amplos, viagens que almejavam chegar à Senegâmbia eram pelo menos 50 por cento mais curtas que as para o resto da África Ocidental e Central atlântica. Viagens trazendo escravos da costa Índica eram, por outro lado, substancialmente mais longas do que quaisquer outras. Na larga região que se estende da Costa do Ouro ocidental até o sul de Angola, da qual uns 85 por cento dos escravos foram trazidos, existiam grandes diferenças entre uma área de embarque e outra em termos de duração da viagem e, portanto, de custos. Estes derivavam em parte das correntes oceânicas e dos regimes de ventos prevalecentes. Desse modo, era em geral mais rápido velejar de Angola até a América do Norte do que navegar entre qualquer ponto entre a Winward Coast e a Baía de Biafra, apesar de Angola ser, geograficamente, mais distante. Além disso, durante o pico da era do comércio negreiro, os navios podiam obter seus escravos mais depressa na Baía de Biafra, especialmente no porto de Bonny, do que em qualquer outra região africana. ${ }^{19}$

\section{Tabela 3 - Tempo médio de viagem de navios negreiros a partir de portos da Europa e das Américas que retornaram para Saint Domingue e Jamaica, de acordo com as grandes regiões de proveniência dos escravos na África, qüinqüênios selecionados, 1676-1795 (número de viagens entre parênteses)}

\begin{tabular}{|c|c|c|c|c|c|}
\hline & $1676-1705$ & $1751-1755$ & $1771-1775$ & $1786-1790$ & $1791-1795$ \\
\hline Alta Guiné & $225.9^{* * *}$ & 314.4 & 312.0 & $259.5^{* * *}$ & $300.4^{* * *}$ \\
& $(10)$ & $(42)$ & $(21)$ & $(85)$ & $(55)$ \\
Costa do Ouro & 280.6 & $357.9^{* * *}$ & 303.6 & $300.4^{* * *}$ & $313.9^{* * *}$ \\
& $(20)$ & $(66)$ & $(14)$ & $(64)$ & $(44)$ \\
Baía de Benin & $335.3^{*}$ & $366.6^{* * *}$ & 347.0 & $348.0^{* * *}$ & $324.1^{* * *}$ \\
& $(42)$ & $(54)$ & $(46)$ & $(85)$ & $(20)$ \\
Baía de Biafra & 305.9 & 302.6 & 339.9 & 249.2 & 252.7 \\
& $(14)$ & $(46)$ & $(16)$ & $(105)$ & $(122)$ \\
Africa Central & $346.3^{*}$ & $361.6^{* * *}$ & 359.2 & $370.9^{* * *}$ & $275.3^{*}$ \\
Atlântica & $(29)$ & $(53)$ & $(107)$ & $(179)$ & $(105)$ \\
Africa Oriental & & & & $487.5^{* * *}$ & $444.3^{* * *}$ \\
e do Sul & & & & $(37)$ & $(9)$ \\
Todas as & 315.4 & 343.7 & 346.8 & 327.3 & 283.2 \\
regióes*** & $(115)$ & $(261)$ & $(205)$ & $(555)$ & $(355)$ \\
\hline
\end{tabular}


Para as equaçôes nas quais esta tabela está baseada ver Apêndice 5.

* Significativamente diferente da média da Baía de Biafra, nível de 20 por cento.

** Significativamente diferente da média da Baía de Biafra, nivel de 5 por cento

*** Significativamente diferente da média da Baia de Biafra, nivel de 1 por cento

**** Inclui algumas regióes não listadas em linhas anteriores

Fonte: David Eltis, Stephen D. Behrendt, David Richardson, e Herbert S. Klein, The Transatlantic Slave Trade: A Database on CD-ROM (Cambridge, 1999), Apêndice 5

Estas diferenças são destacadas na tabela 3, que apresenta o tempo médio em dias de navegação gastos das Américas ou da Europa para várias regiōes africanas e em seguida para o Caribe ocidental — definido aqui como a Jamaica ou Saint Domingue. A maior parte dos navios desta amostragem é francesa e britânica. Por razões que se tornarão claras em breve, apenas dados de períodos selecionados são aqui apresentados. A tabela 3 incorpora os resultados de testes de pertinência estatística usando uma análise de regressão baseada no apêndice 5. Dois padrões são imediatamente evidentes a partir da tabela. O primeiro: para a maioria dos anos mostrados os navios negreiros que obtinham seus escravos na Baía de Biafra completavam as viagens até os importantes centros de comercialização de cativos no Caribe muito mais rapidamente do que os navios que faziam comércio com outras regiōes. Em média, na segunda metade do século dezoito, tais viagens eram quase 15 por cento mais rápidas que aquelas vindas de regióes adjacentes. Tal vantagem derivava do período de tempo necessário para coletar uma carga humana completa, e não de diferenças de tempo gasto no mar. Em segundo lugar, as vantagens da Baía de Biafra aumentaram com o passar do tempo, chegaram a um pico na década de 1780 e então - apesar disso não ser mostrado na tabela 3 - provavelmente desapareceram depois de $1800 .{ }^{20}$ Ademais, existe hoje em dia considerável evidência de que a mortalidade a bordo não era a mesma para todas as regiōes de partida, ou até mesmo para os portos de cada região. Além disso, dada a natureza destas mortes, morbidade e mortalidade estavam intimamente relacionadas, de forma que os escravos que sobreviveram à provação da travessia oceânica vindos de regiōes de alta mortalidade eram mais fracos e, portanto, vendidos por menos do que aqueles oriundos de regióes de baixa mortalidade. Mais uma vez estas diferenças concentram- 
se na Baía de Biafra, de onde partiam navios que, durante a maior parte da era do tráfico, experimentaram uma mortalidade em média um terço maior do que os navios que indo para os mesmos destinos partiam da África Central Atlântica e da Baía de Benin. Curiosamente, este diferencial desaparece depois de 1807, quando a mortalidade a bordo é incrementada em todos os lugares durante a fase ilegal do comércio de escravos. As implicações destes padrões de preços derivam do fato de que os custos de transporte (inclusive as perdas por mortalidade a bordo) respondem por mais de 50 por cento do preço de venda do escravo recém-desembarcado. Em resumo, não se poderia esperar que os preços de venda para escravos que aportam nas Américas vindos de diferentes regióes africanas possam ter sido os mesmos. ${ }^{21}$

A tabela 4 enfoca os agrupamentos regionais africanos para os quais é possível realizar testes estatísticos formais. Apresentamos aqui os dados do corte seccional de preços nas Américas para escravos provenientes de diferentes regiōes africanas. O dois qüinqüênios aos quais se relacionam os dados de antes do ápice do comércio negreiro - 1676-1680 e 1701-1705 — mostram diferenças estatisticamente pouco significativas entre regiões africanas. As amostras para as regiôes de custo baixo e alto - Alta Guiné e África do Sul e Oriental, respectivamente —, são pequenas ou não existentes, mas as oito amostras nestes dois qüinqüênios, relativas às regióes africanas do oeste e ao Congo-Angola apontam para apenas uma diferença significativa, e isso em um nível de somente vinte por cento. Isso sugere que no princípio do crescimento do comércio negreiro, as diferenças de preços entre as regióes eram pequenas e que os mercados estavam provavelmente bem integrados. Mesmo que tal não esteja demonstrado nas tabelas, nos parece que esta situação pode ter influenciado o término do comércio. Para o período posterior a 1790 existem para Cuba dados muito bons e que diferenciam a região africana de origem, mas a identificação das "nações africanas" para a América espanhola como um todo deve merecer cuidado. Os dados nem sempre são fixos (as identidades étnicas poderiam mudar com o passar do tempo) nem precisos, e atribuí-los às oito zonas do litoral africano definidas na tabela 1 representa um problema adicional. ${ }^{22}$ Enquanto Laird Bergad e seus colegas demonstram as diferenças entre preços médios pagos por cada uma destas nações, testes com agru- 
pamentos de homens entre as idades de 15 e 40 anos por períodos de cinco anos revelaram que as diferenças não são, de fato, estatisticamente significantes para qualquer momento do século dezenove.

\section{Tabela 4 - Preços nominais médios, em libras esterlinas padronizadas para a Jamaica, de homens escravos recentemente chegados às Américas, por regiões de partida da África, qüinqüênios selecionados, 1676-1795 (número de escravos vendidos entre parênteses)}

\begin{tabular}{|c|c|c|c|c|c|c|}
\hline & $1676-80$ & $1701-1705$ & $1751-1755$ & $1771-1775$ & $1786-1790$ & $1791-1795$ \\
\hline Alta Guiné & $15.7^{*}$ & 26.2 & $34.3^{* * *}$ & $47.9^{* *}$ & 50.8 & $60.5^{*}$ \\
& $(184)$ & $(363)$ & $(1277)$ & $(2472)$ & $(4045)$ & $(2490)$ \\
Costa do & 19.8 & $28.9^{*}$ & $34.9^{* * *}$ & $47.5^{* *}$ & $58.5^{* * *}$ & $65.7^{* * *}$ \\
Ouro & $(2945)$ & $(3465)$ & $(4129)$ & $(4350)$ & $(2742)$ & $2627)$ \\
Baía de Benin & 18.6 & 27.5 & 32.9 & $48.5^{* *}$ & $67.5^{* * *}$ & 58.0 \\
& $(2482)$ & $(5115)$ & $(391)$ & $(2568)$ & $(1979)$ & $(207)$ \\
Baía de Biafra & 18.8 & 23.9 & 26.1 & 42.7 & 48.1 & 54.7 \\
& $(2401)$ & $(468)$ & $(2171)$ & $(5296)$ & $(7515)$ & $(8193)$ \\
Africa & 18.1 & 21.0 & $34.7^{* *}$ & $49.4^{* * *}$ & $77.4^{* * *}$ & $63.7^{* *}$ \\
Central & $(1117)$ & $(798)$ & $(7943)$ & $(4403)$ & $(5114)$ & $(2377)$ \\
Atlântica & & & & & & \\
Africa & & & & & & \\
Oriental e \\
do Sul
\end{tabular}

Para as equaçōes em que esta tabela é baseada ver tabela do Apêndice 5.

* Significativamente diferente da média da Baía de Biafra, nivel de 20 por cento. ** Significativamente diferente da média da Baía de Biafra, nivel de 5 por cento *** Significativamente diferente da média da Baía de Biafra, nivel de 1 por cento ****Inclui algumas regiōes não listadas em linhas anteriores

Fonte: David Eltis, Stephen D. Behrendt, David Richardson, e Herbert S. Klein, The Transatlantic Slave Trade: A Database on CD-ROM (Cambridge, 1999), Tabela 3

Por contraste, no ápice do comércio na segunda metade do século dezoito, os escravos vindos de áreas diferentes no que se poderia chamar de "coração da origem dos cativos" na África Ocidental e na África Central 
Atlântica eram vendidos por preços substancialmente distintos nas Américas (após o ajuste para as distâncias entre mercados diferentes). A tabela 4 apresenta grandes diferenças entre os quatro qüinqüênios centrados na Baía de Biafra. Os escravos daquela região eram vendidos nas Américas por algo entre um quinto e um terço a menos do que aqueles vindos de todas outras áreas costeiras durante o mesmo período. Estas diferenças são estatisticamente significativas, situando-se em níveis de um a cinco por cento para cada qüinqüênio na Costa do Ouro e em Angola, e para a Alta Guiné e Baía de Benin em dois dentre quatro qüinqüênios. As diferenças são maiores no início de 1750 e no final da década de 1780 . Desse modo, a expectativa de que escravos de regiōes diferentes na África fossem vendidos a preços diferentes é, de fato, justificada.

Tabela 5 - Preços em libra esterlina, padronizadas para a Jamaica, de homens escravos recentemente chegados às Américas, por regiões africanas de partida, qüinqüênios selecionados, 1676-1795 (número de escravos vendidos ente parênteses)

\begin{tabular}{|c|c|c|c|c|c|c|c|c|c|}
\hline & $\begin{array}{c}1671- \\
1675\end{array}$ & $\begin{array}{c}1676- \\
1680\end{array}$ & $\begin{array}{l}1681- \\
1685\end{array}$ & $\begin{array}{l}1686- \\
1690\end{array}$ & $\begin{array}{c}1691- \\
1695\end{array}$ & $\begin{array}{c}1696- \\
1700\end{array}$ & $\begin{array}{l}1701- \\
1705\end{array}$ & $\begin{array}{c}1706- \\
1710\end{array}$ & $\begin{array}{l}1741- \\
1745\end{array}$ \\
\hline $\begin{array}{c}\text { Carolina } \\
\text { do Sul }\end{array}$ & & & & & & & & & $\begin{array}{c}18.1^{* * *} \\
(230)\end{array}$ \\
\hline Guianas & & & & & & & & & $\begin{array}{l}29.7^{* *} \\
(1653)\end{array}$ \\
\hline Jamaica & $\begin{array}{c}25.0 \\
(1249)\end{array}$ & $\begin{array}{c}19.9 \\
(4225)\end{array}$ & $\begin{array}{c}17.6 \\
(3480)\end{array}$ & $\begin{array}{c}19.8 \\
(4770)\end{array}$ & $\begin{array}{c}19.8 \\
(2383)\end{array}$ & $\begin{array}{c}23.1 \\
(1163)\end{array}$ & $\begin{array}{c}24.4 \\
(2724)\end{array}$ & $\begin{array}{c}25.9 \\
(1727)\end{array}$ & \\
\hline $\begin{array}{c}\text { Saint } \\
\text { Domingue }\end{array}$ & & & & & & & & & $\begin{array}{c}38.5^{*} \\
(1980)\end{array}$ \\
\hline $\begin{array}{l}\text { Dominica, } \\
\text { São Vicente e } \\
\text { Granada }\end{array}$ & & & & & & & & & \\
\hline $\begin{array}{l}\text { Barbados e } \\
\text { Antígua }\end{array}$ & $\begin{array}{c}20.4^{* * *} \\
(1643)\end{array}$ & $\begin{array}{l}18.0^{* *} \\
(5083)\end{array}$ & $\begin{array}{c}17.0 \\
(3941)\end{array}$ & $\begin{array}{c}18.7 \\
(3835)\end{array}$ & $\begin{array}{l}21.5^{*} \\
(3106)\end{array}$ & $\begin{array}{l}25.4^{*} \\
(5321)\end{array}$ & $\begin{array}{c}26.0 \\
(9397)\end{array}$ & $\begin{array}{c}24.8 \\
(5639)\end{array}$ & $\begin{array}{c}35.1 \\
(1492)\end{array}$ \\
\hline $\begin{array}{c}\text { Todas as } \\
\text { Regiōes**** }\end{array}$ & $\begin{array}{c}21.0 \\
(2892)\end{array}$ & $\begin{array}{c}18.4 \\
(9334)\end{array}$ & $\begin{array}{c}16.8 \\
(7421)\end{array}$ & $\begin{array}{c}19.4 \\
(9397)\end{array}$ & $\begin{array}{c}21.4 \\
(5798)\end{array}$ & $\begin{array}{c}24.9 \\
(7640)\end{array}$ & $\begin{array}{c}26.2 \\
(13242)\end{array}$ & $\begin{array}{c}25.3 \\
(7969)\end{array}$ & $\begin{array}{c}29.3 \\
(8718)\end{array}$ \\
\hline
\end{tabular}


Tabela 5 (cont.)

\begin{tabular}{|c|c|c|c|c|c|c|c|c|}
\hline & $1751-$ & $1756-$ & $1766-$ & $1771-$ & $1776-$ & $1781-$ & $1786-$ & $1791-$ \\
& 1755 & 1760 & 1770 & 1775 & 1780 & 1785 & 1790 & 1795 \\
\hline Carolina & 35.1 & $31.0^{* * *}$ & 38.7 & $53.0^{* *}$ & & $58.5^{*}$ & & \\
do Sul & $(1049)$ & $(1923)$ & $(514)$ & $(2428)$ & & $(790)$ & & \\
Guianas & $36.6^{*}$ & $28.0^{* * *}$ & $48.0^{* *}$ & $43.0^{* * *}$ & 44.1 & 51.5 & 54.4 & 65.5 \\
& $(1618)$ & $(2447)$ & $(3024)$ & $(2525)$ & $(1175)$ & $(145)$ & $(669)$ & $(939)$ \\
Jamaica & 32.6 & 36.7 & 40.6 & 49.0 & 41.0 & 47.1 & 52.5 & 59.7 \\
& $(4040)$ & $(4014)$ & $(1390)$ & $(6171)$ & $(5536)$ & $(1168)$ & $(6917)$ & $(11959)$ \\
Saint & 35.4 & $45.6^{*}$ & $51.9^{* *}$ & $53.4^{* *}$ & $50.2^{* * *}$ & $65.5^{* * *}$ & $73.9^{* * *}$ & 63.1 \\
Domingue & $(688)$ & $(588)$ & $(622)$ & $(3426)$ & $(1448)$ & $(8282)$ & $(11016)$ & $(2280)$ \\
Dominica, São & & & 39.1 & $41.9^{* * *}$ & $35.6^{* *}$ & 42.0 & $48.2^{* *}$ & $53.3^{*}$ \\
Vicente e & & & $(2144)$ & $(3574)$ & $(1279)$ & $(1493)$ & $(5565)$ & $(1725)$ \\
Granada & & & & & & & & \\
Barbados e & $26.6^{* *}$ & $29.0^{* *}$ & $34.6^{*}$ & $42.7^{* * *}$ & 37.5 & 43.2 & $48.3^{*}$ & 51.6 \\
Antigua & $(1422)$ & $(681)$ & $(750)$ & $(1610)$ & $(442)$ & $(1067)$ & $(1300)$ & $(745)$ \\
Todas as & 33.0 & 32.8 & 42.6 & 46.1 & 41.2 & 57.5 & 59.3 & 59.2 \\
Regiōes**** & $(10652)$ & $(12494)$ & $(9353)$ & 22860 & $(11533)$ & $(14770)$ & $(25803)$ & $(18044)$ \\
\hline
\end{tabular}

Para as equaçôes em que esta tabela é baseada ver apêndice 4.

* Significativamente diferente da Jamaica, nivel de 20 por cento (com exceção de 1741-45 quando a referência for Barbados e Antígua).

** Significativamente diferente da Jamaica, nivel de 5 por cento (com exceção de 1741-45 quando a regiāo de referência for Barbados e Antígua).

*** Significativamente diferente da Jamaica, nivel de 1 por cento (com exceção de 1741-45 quando a regiāo de referência for Barbados e Antígua).

**** Inclui algumas regióes não listadas em linhas anteriores

Fonte: David Eltis, Stephen D. Behrendt, David Richardson, e Herbert S. Klein, The Transatlantic Slave Trade: A Database on CD-ROM (Cambridge, 1999), Apêndice 4

Para as Américas, a tabela 5 mostra o resultado de análise semelhante para esses preços padronizados a partir da Jamaica em sete mercados no Caribe e para os Estados Unidos. A tabela fornece os resultados de uma análise de regressão baseada na variância observada para esses importantes mercados. Foi necessário agruparmos Antígua e Barbados em um único mercado; e Dominica, São Vicente e Granada em outro, pelos requisitos de tamanho de amostra para efeito de testes de significância. Estas ilhas, em todo caso, mantinham estreitas relações mercantis entre si e compara- 
ções dentro do grupo não apresentam nenhuma diferença significativa para aqueles qüinquiênios cujos dados são adequados. Os sete mercados juntos foram responsáveis pelo negócio de quase noventa por cento do total de escravos não-brasileiros antes de 1808, e a Jamaica, Barbados, São Vicente, Dominica e Granada foram, em épocas diferentes, importantes entrepostos a partir dos quais a América espanhola, as Windward francesas, e alguns pequenos territórios ingleses adquiriram muitos de seus escravos em um tráfico interamericano de escravos. ${ }^{23}$ É improvável que o padrão geral de preços de escravos variasse acentuadamente em relação àquele que vigorava para os mercados maiores.

A tabela 5 revela diferenças de preços que não podem ser explicadas apenas pelos custos de transporte entre mercados. Entre 1673 e 1690, e novamente no terceiro quarto do século dezoito, os preços de escravos na Jamaica eram mais altos que aqueles praticados em Barbados — uma diferença maior do que a quantia necessária para pagar custos de transporte entre estas duas ilhas. Conquanto não existissem significativos diferenciais de preço tanto no início como no último quarto do século dezoito, houve uma reversão súbita e temporária do premium jamaicano durante a década de 1690, quando a guerra generalizada trouxe para as ilhas a real ameaça de uma invasão francesa, e a Jamaica perdeu temporariamente seu papel de importante entreposto para compradores hispano-americanos de escravos. Depois de 1740, as sondagens estatísticas sugerem um mercado funcionando em três níveis, encabeçado por Saint Domingue, com a Jamaica em segundo lugar e a maioria dos outros pagando mais uma vez preços mais baixos formando o terceiro nível. Exceções ocasionais para este padrão foram as Guianas holandesas na segundo metade da década de 1760, e a Carolina do Sul no início de 1770, quando o preço dos escravos temporariamente se estabilizou nos níveis de Saint Domingue. Como se poderia esperar, estes foram períodos nos quais os setores de plantation de ambas as regióes conheceram forte expansão e grande prosperidade. ${ }^{24}$ Talvez, porém, as mais notáveis diferenças sejam aquelas ocorridas dentro de uma mesma macroregião, como as que se desenvolveram na segunda metade do século dezoito. Jamaica e Saint Domingue estão a distâncias semelhantes das zonas mais importantes de proveniência de escravos africanos, o Caribe Oriental, e tinham os mesmos problemas de ventos e correntes para a navegação de 
navios vindos do leste. Ainda assim, entre 1760 e 1790 os preços de escravos eram em média 20 por cento mais altos em Saint Domingue do que na Jamaica e, efetivamente, maiores do que em qualquer outro lugar nas Américas que comprasse escravos da África. Diferenças desenvolveram-se até mesmo dentro de Saint Domingue, com os plantadores no norte da colônia pagando preços nominais substancialmente mais baixos do que aqueles do oeste e do sul. ${ }^{25}$ Por contraste, os preços de escravos nas colônias francesas e holandesas da América do Sul, nas ilhas britânicas menores e nos Estados Unidos em geral ficavam atrás dos praticados nos grandes mercados caribenhos em uma diferença maior do que teria sido o custo de transportar escravos de um mercado para o outro. Quando consideramos o tamanho do mercado de escravos após 1660, merece particular atenção a razoável facilidade de entrada na África, na Europa e nas Américas, e o que tem sido há tempos considerado como a incompetência da parte dos governos para moldar o mercado através de regulamentações mercantilistas, a persistência destas diferenças regionais nas Américas e, de forma mais branda, na África.

V

A escalada conjunta de preços e quantidade de escravos durante mais de 125 anos é seguramente o indicativo do aumento secular na demanda por escravos, baseada sem dúvida na expansão da produção de açúcar. Se de fato a curva de oferta agregada de escravos vindos da África Ocidental, da região congo-angolana e do Índico se manteve constante neste período, como requeria a demanda, então entre 1676 e 1810 a elasticidade dos preços de oferta de escravos teria sido considerável. A quadruplicação dos preços e um aumento de duas vezes e meia no número de escravos vendidos sugere uma elasticidade da esfera da oferta que mais do que dobrava. Durante o século XVIII, a composição dos custos da oferta dos escravos recém-aportados nas Américas compunha-se mais ou menos de 50 por cento para o transporte transatlântico, 25 por cento de gastos de armazenamento na costa africana e 25 por cento de gastos de obtenção e entrega dos cativos para seus donos ou feitores na costa americana. No curso do século dezoito, não parecem ter ocorrido grandes inovações tecnológicas 
nos dois primeiros custos. Os tempos de viagem aumentaram ligeiramente e o quinhão dos preços de escravos nas Américas absorvido pelo transporte diminuiu um pouco, enquanto a razão preço do africano/preço do crioulo aumentou. Já para a África, sabe-se menos sobre a composição de oferta, mas temos conhecimento de que no terceiro quarto do século dezoito o tempo gasto para obter um carregamento completo de escravos aumentou abruptamente, sugerindo um nítido crescimento dos custos no interior. ${ }^{26}$ Ao final do século o tempo de espera para obtenção de escravos reverteu para níveis anteriores, mas em meados do Setecentos tal aumento sem dúvida compensava a pequena melhoria dos tempos de travessia oceânica.

Depois de 1810 encontramos uma situação bastante distinta. Mesmo com a demanda continuando a aumentar devido ao impacto da industrialização e às rendas crescentes na Europa, ocorreram mudanças importantes na oferta de escravos, provocadas pela abolição do tráfico. A abolição como fator manifesto na interferência naval sobre o comércio e, ainda mais importante, como subornos volumosos para funcionários dos governos do Brasil e de Cuba para permitir as cargas ilegais, representou uma importante variável de custos, que aumentou os preços nas Américas e reduziuos na costa africana. ${ }^{27}$ Os tempos de duração das viagens melhoraram nitidamente no século dezenove, mas tal impacto custo-redutor era mais do que contrabalançado pelas medidas tomadas para permitir a fuga da ira dos cruzadores britânicos, pelas despesas com pontos alternativos de desembarques nas Américas, e pelos subornos referidos. A maior parte do impacto foi acusada depois de 1840, quando os preços aumentaram mais fortemente. É particularmente notável que este padrão tenha se mantido naqueles países que continuaram a aceitar novas chegadas de escravos Cuba e Brasil - e também naqueles que não o fizeram, como os EUA e, antes de 1833, o Caribe britânico. É também notável que este tenha sido o período no qual o tráfico interamericano de escravos ascendeu, com os donos deslocando seus escravos dentro de cada uma das grandes zonas de escravatura. Mesmo que os britânicos tenham conseguido manter o comércio intercaribenho de sua própria zona colonial em níveis bastante baixos, eles não podiam prevenir o aparecimento de enormes diferenciais no preço de escravos em ilhas adjacentes às Índias Ocidentais, ocorridos entre a abolição do comércio negreiro para territórios ingleses e a abolição da es- 
cravidão propriamente dita. ${ }^{28} \mathrm{O}$ fato de os donos de escravo poderem pagar preços relativamente altos no Brasil, em Cuba, nos EUA, em Trinidad e nas Guianas britânicas indica que a produtividade de trabalho estava também aumentando intensamente, um assunto que tem sido extensamente explorado na literatura nos últimos trinta anos.

Do lado africano, dado o padrão de envolvimento regional no comércio esboçado no princípio deste trabalho, é provável que as grandes zonas de proveniência apresentassem estruturas de custo diferentes na esfera da oferta de escravos. O mesmo preço oferecido por um escravo numa determinada regiáo obteria uma quantidade diferente de cativos em nada menos do que oito regióes e, como os preços subiram depois de 1675, cada uma delas responderia de modo diferente, ou, mais formalmente ainda, exibiria elasticidades diferenciadas. Um preço-limite, abaixo do qual a oferta pode ser considerada como altamente inelástica, seria necessário para trazer uma região costeira (e mesmo uma do interior) para o comércio, e em função dele a resposta em termos de volume de escravos oferecidos poderia ser bastante contundente. Deste modo, cada região seria trazida para o tráfico (como também o deixaria durante a era da abolição) em tempos diferentes, de acordo com o padrão descrito acima. Há aqui analogias com os mercados de trabalho qualificado, nos quais os períodos de treinamento longos asseguram uma forte pressão sobre a remuneração durante curtos períodos enquanto a demanda sobe, e uma pressão muito mais moderada no final, quando a oferta se equipara à demanda. Muitos produtos primários baseados em capital intensivo como o petróleo ou, no período em questão, como o açúcar, mostram os mesmos grandes diferenciais em resposta a mudanças de preços a curto e longo prazos. Para a escravidão, as guerras podiam render uma onda de cativos que encheriam muitos navios transatlânticos, mas não eram nem confiáveis nem previsíveis o suficiente para fornecer uma base segura para uma cadeia de comércio transatlântico ancorada na coordenação de um fluxo de bens e serviços de cinco ou seis continentes e para sincronizar a partida e chegada de navios de acordo com as colheitas tanto na África quanto nas Américas. ${ }^{29}$

Para o comércio de escravos dentro da África, os ajustes-chave eram de natureza provavelmente tanto sociocultural quanto econômica. Uma rede alternativa e mais segura para a oferta de escravos não podia aparecer 
de uma hora para a outra. Ajustes culturais, especificamente mudanças de valores nas percepções de quem era passível de escravização, podem ter sido um pré-requisito para esta rede, e a diversidade social da África subsaariana sugere grandes variações regionais ao longo desse período de ajustes. Uma medida de certo modo tosca mas possível surge a partir da aferição do lapso de tempo entre os primeiros escravos levados para o tráfico transatlântico em cada região e o período em que ocorreu o efetivo aumento do volume de escravos vendidos. Tal lapso parece ter sido menor na África Central Atlântica (uma área tão vasta que é difícil descrevê-la como uma única região), de onde as partidas em larga escala de escravos para o Novo Mundo já aconteciam em meados do século dezesseis. Na Baía de Biafra, por contraste, os escravos são descritos como deixando o delta do Níger e áreas do rio Cross no início do século dezessete, mas oitenta por cento de todos os escravos que deixaram a região foram levados pelo tráfico apenas depois de 1740 - muitas décadas depois do acúmulo de severas pressões de demanda, conforme a figura 1 .

A Costa dos Escravos e a África Central Atlântica apresentaram limites relativamente baixos, seguidos de uma alta elasticidade de preços na esfera da oferta, enquanto as três regiôes da Alta Guiné - especialmente Serra Leoa e a Windward Coast - e a África Oriental e do Sul (pelo menos no que diz respeito ao comércio do Atlântico) tiveram seus níveis iniciais de preços mais altos. A Costa do Ouro, cuja entrada no tráfico esteve provavelmente relacionada ao esgotamento de depósitos de ouro, e a Baía de Biafra situam-se entre estes dois extremos. Ademais, dentro da Baía de Biafra, dois pontos de embarcação importantes, a Velho e Novo Calabar, envolveram-se no comércio negreiro no século dezessete, quando os preços eram baixos, enquanto a ascensão do maior porto de embarque escravo, Bonny, pode ter sido calcada num preço de limite muito mais alto, que evoluiu na segunda metade do século dezoito e esteve associado ao enorme aumento das partidas de escravos através da Baía de Biafra durante aquele período. Deste modo, a exploração plena do sistema de Bonny exigia um preço mais alto que o possível no século dezessete. Vale a pena notar neste contexto que a área geográfica da qual Bonny extraía escravos era provavelmente muito maior do que aquela de Calabar, e que os comerciantes de Bonny talvez dependessem mais da complexa rede cultural de Aro do que os de Calabar para a consecução da oferta de escravos. ${ }^{30}$ 
Assim, os diferenciais africanos de preços são consistentes, com diferenças de longo e curto termo das elasticidades da oferta em regióes (e portos), assim como diferenciais inter-regionais igualmente de longo e de curto termo. Parte deste padrão se manifesta nas Américas. A tabela 5 fornece exemplos de diferenciais de preço temporários entre regiōes durante qüinqüênios específicos, sobretudo quando os mercados para o comércio de escravos se expandiam rapidamente, e mostra também o desaparecimento desses mercados de longo prazo. Entre 1673 e 1680 a Jamaica não apenas entrava no mercado de açúcar, mas estava tornando-se o mais importante entreposto no comércio negreiro na América espanhola. ${ }^{31}$ Por seu turno, nos anos de 1670 Barbados já sofria sua primeira revolução do açúcar. Por um período, os diferenciais de preço eram mais do que suficientes para pagar o custo de transporte entre as duas ilhas, mas um equilíbrio calcado em custos de transporte já estava aparentemente funcionando por volta de 1680 , quando o diferencial de preço desapareceu. Depois de 1690, os preços na Jamaica ficaram atrás dos de Barbados durante dois qüinqüênios; entretanto, estes resultados são significativos apenas num nível de 20 por cento. Este foi um período no qual a guerra interferia no fluxo de escravos da Jamaica para a América espanhola e testemunhou violentos ataques franceses ao norte da ilha. ${ }^{32} \mathrm{O}$ equilíbrio foi prejudicado mais uma vez no terceiro quarto do século dezoito, quando a Jamaica expandia rapidamente a produção de açúcar mascavo, e Barbados estava diversificando-se rumo a subprodutos açucareiros menos trabalhosos como o rum e o melaço. $\mathrm{Na}$ maioria dos qüinqüênios entre 1751 e 1775, um escravo masculino-padrão é estimado como tendo um custo 20 por cento maior na Jamaica do que em Barbados, após correção dos custos de transporte. Algumas diferenças de curto prazo aparecem também na Carolina do Sul do século dezoito. Ainda nos faltam informações de preço para o período anterior e posterior ao primeiro borbotão das chegadas maciças de escravos ocorridas antes da Rebelião de Stono em 1739 — ignorando os qüinqüênios com pequenas amostragens, bem como os ápices de 1804-07. No dois qüinqüênios antes da Revolução, quando os números tornam os testes estatísticos possíveis, os preços de escravos nesta colônia ficavam para trás dos preços praticados na Jamaica em 1756-60, e nos prósperos qüinqüênios anteriores à Revolução os plantadores da Carolina do Sul podiam pagar os 
mesmos preços que Saint Domingue — diferentemente de seus pares jamaicanos.

Mas as diferenças mais importantes nos preços da tabela 5 têm pouco que ver com ajustes de longo e de curto prazo. Nas Américas, mercados de escravos altamente segmentados, e mesmo os de outros produtos, eram a norma antes do século dezenove, quando mais de dois terços de todos africanos escravizados fizeram a viagem para as Américas. Existiam cinco sistemas transatlânticos diferentes vigentes durante a maior parte desta época — britânico, francês, holandês, espanhol e português - e um sexto se incluirmos os EUA independentes. O preço do açúcar em Amsterdã ou na Alemanha do Norte, onde era vendido o açúcar excedente de todos os sistemas europeus, agia talvez como o último árbitro sobre o preço de escravos na América. Mas os mercados para o açúcar eram eles mesmos segmentados, incluindo tarifas e subsídios para permitir diferenças regionais no que os plantadores podiam pagar por seu trabalho. Cada poder colonial podia impor algumas restrições mercantilistas que preservavam o mercado doméstico de açúcar bem como o mercado colonial de escravos para os seus próprios comerciantes. Deste modo, por exemplo, navios ingleses não podiam negociar livremente na América francesa sem primeiro se registrarem como propriedade francesa (um procedimento arriscado e caro), ou no Brasil e na América espanhola sem uma autorização. Além disto, o governo francês subsidiou o comércio de escravos. Estas restriçóes e preferências eram obviamente bastante porosas. O contrabando ocorria em grande escala, e as empresas britânicas encontraram meios para registrar seus navios como franceses. Não obstante, se medirmos o que teria acontecido na ausência destas barreiras — um padrão que os economistas mais provavelmente usariam - ao invés do que teria ocorrido se as leis fossem 100 por cento efetivas, concluiremos que o mercantilismo era de fato muito eficiente.

Por conseguinte, no ápice do comércio escravocrata no Caribe Ocidental, existiam três grandes mercados adjacentes para escravos, Saint Domingue, Jamaica e Cuba, os quais tiveram uma interação muito menor do que teriam sob de condições de livre comércio. A tabela 5 mostra que antes de 1795 os diferenciais de preços detectados entre os sistemas escravistas da Inglaterra, França e Cuba eram muito mais significativos do que aqueles observados entre as regiōes contidas dentro de cada sistema, mes- 
mo depois de corrigir os custos de transporte. Os preços em Saint Domingue eram normalmente de 25 a 30 por cento maiores do que os na Jamaica. $\mathrm{Na}$ verdade, os preços para africanos recém-chegados eram consistentemente maiores em Saint Domingue do que em qualquer outro lugar das Américas entre 1756 e a rebelião que destruiu a colônia, iniciada em agosto de 1791. Em Cuba, entre 1786 e 1790 eles alcançaram níveis que não foram ultrapassados até os idos de 1840. Tal padrão é inteiramente congruente com a extraordinária emergência da colônia francesa à condição de líder do mercado mundial de açúcar, e também de café e índigo. $\mathrm{O}$ próximo ápice de preços a ultrapassar o de 1786-90 correspondeu a Cuba, que alcançou uma posição de semelhante domínio mundial no mercados de açúcar no início da década de $1840 .{ }^{33}$ No terceiro quarto do século dezoito, porém, Cuba estava efetivamente impossibilitada de competir com Saint Domingue e com a Jamaica, em função da severidade das políticas coloniais da metrópole espanhola. A tabela 5 não contém dados cubanos para este momento porque, excetuando a fase da ocupação britânica de Havana em 1762-3, poucos escravos vindos diretamente da África eram vendidos em Cuba antes do fim dos anos 1780. Os escravos que eram vendidos, principalmente os crioulos, eram-no por preços muito acima dos praticados na Jamaica, em níveis que colaboravam para a lentidão do desenvolvimento da indústria de açúcar cubana (entre um e dois séculos) se, como parece razoável crer, tal padrão tivesse também existido no início do século dezessete. ${ }^{34}$ As diferenças entre os sistemas britânico e holandês também aparecem no terceiro quarto do século dezoito, quando o comércio de escravos aproximava-se de seu pico. Todas as observações disponíveis sobre as Guianas para esta época provêm da América do Sul holandesa, principalmente do Suriname. A região parece ter operado com alguma independência dos mercados principais, com os seus preços de escravos geralmente abaixo do verificado no resto das Américas, apesar de durante o período de forte expansão do açúcar, os preços no Suriname de 1766-70 terem se aproximado temporariamente daqueles de Saint Domingue. Depois disso, e particularmente após 1780, as diferenças desaparecem - entretanto, os tamanhos de amostras para as Guianas diminuem. Foi neste momento que os britânicos destruíram a frota holandesa de navios negreiros e começaram eles mesmos a prover escravos para as colônias holandesas, com os 
plantadores britânicos se estabelecendo cada vez mais em Demerara, em Berbice e em Essequibo. Parece claro que depois de 1775 as barreiras entre os sistemas inglês e holandês erodiram-se significativamente, com os diferenciais de preços de escravo seguindo o exemplo.

Em termos gerais, as tendências nos preços e quantidades de escravos em 1673-1867 podem encontrar sua explicação na dinâmica mercadológica da esfera da demanda até o início do século dezenove. Depois disso, e pelo menos da perspectiva dos mercados de escravos nas Américas, a oferta (ou, mais precisamente, os esforços para suprimir este comércio) passou a desempenhar um papel muito mais fundamental. A importância central do açúcar, do lado da demanda, é clara. Como o comércio de escravos não feneceu por causa de um colapso na demanda, os fatores relativos à esfera da oferta é que produziram o efeito terminal sobre o tráfico, no sentido de que se tornou demasiadamente caro pagar os custos de impedir sua abolição. Ao longo da era do comércio negreiro, os mercados do lado africano do Atlântico parecem ter sido mais integrados do que os do lado americano. Existiam diferenças importantes entre as grandes regiōes africanas que claramente determinavam os preços e quantidades de escravos vendidos no litoral em resposta a uma demanda do Atlântico (que se somava à demanda doméstica por escravos). Além disto, os traficantes europeus e africanos eram às vezes capazes de obter outros rendimentos em alguns portos específicos de embarque. ${ }^{35}$ Mas não existia na África os mercados segmentados observados durante grande parte do século dezoito nas Américas, uma característica que pode ter estado conectada com a inabilidade dos europeus em estabelecer sua soberania sobre a África subsaariana antes de meados do século dezenove. Só em Angola, a única região na África onde foi estabelecida a efetiva presença soberana européia, havia mercados reservados com êxito e exclusividade para um grupo nacional de comerciantes de escravos - em Luanda e Benguela. Ironicamente, quando no século dezenove os Europeus mais pareciam capazes de impor mercados segmentados à costa africana através da ocupação direta (do mesmo tipo que ocorreu nas Américas), o comércio de escravos tornou-se alvo de ações repressoras. A partir do final do século dezoito, no caso de Serra Leoa, e do fim das décadas de 1820 e 1830, no caso do Senegal e dos principais portos de Angola, o colonialismo europeu se viu associado à repressão ao comércio negreiro ao invés de com a sua promoção. ${ }^{36}$ 


\section{Apêndice 1 - Médias qüinqüenais dos preços em libras esterlinas de escravos desembarcados nas Américas, distribuídos de acordo com a região africana de embarque, 1671-1810}

\begin{tabular}{|c|c|c|c|c|c|c|c|c|}
\hline & Senegâmbia & Serra Leoa & $\begin{array}{c}\text { Windward } \\
\text { Coast }\end{array}$ & $\begin{array}{c}\text { Costa do } \\
\text { Ouro }\end{array}$ & $\begin{array}{l}\text { Baía de } \\
\text { Benin }\end{array}$ & $\begin{array}{l}\text { Baía de } \\
\text { Biafra }\end{array}$ & $\begin{array}{c}\text { Africa } \\
\text { Central } \\
\text { Atlântica }\end{array}$ & $\begin{array}{c}\text { Africa } \\
\text { Oriental e } \\
\text { do Sul }\end{array}$ \\
\hline $1671-75$ & & & & & $22.7(645)$ & $19.1(536)$ & & \\
\hline $1676-80$ & $14.9(184)$ & & & $19.3(2945)$ & $17.8(2482)$ & $18.4(2401)$ & $17.5(1117)$ & \\
\hline $1681-85$ & $16.4(908)$ & $18.11(137)$ & & $16.2(129)$ & $17.1(2865)$ & $16.8(1268)$ & $16.3(2114)$ & \\
\hline $1686-90$ & $21.1(725)$ & $21.7(354)$ & & $18.7(361)$ & 19(5897) & $20.6(226)$ & $18.5(1834)$ & \\
\hline $1691-95$ & 19.6(1235) & $27.8(131)$ & & $24.7(767)$ & $21.47(3056)$ & $25.5(108)$ & $16(277)$ & \\
\hline $1696-1700$ & $18.3(112)$ & $16(151)$ & & $25.3(2406)$ & $25.8(2775)$ & $22.6(188)$ & $23.3(232)$ & \\
\hline $1701-5$ & $27.6(183)$ & & $23.5(180)$ & $28.9(3465)$ & $27.5(5115)$ & $23.9(468)$ & 21(798) & \\
\hline $1706-10$ & $22.2(576)$ & $24.4(139)$ & & $27(4963)$ & $24.1(1219)$ & $21.3(164)$ & & \\
\hline $1711-15$ & & & & $26.1(315)$ & $24.7(496)$ & & & \\
\hline $1716-20$ & $13.7(211)$ & & & $20.5(471)$ & $17.3(332)$ & & & \\
\hline $1721-25$ & $24.5(1484)$ & $23(63)$ & & $25.6(1922)$ & $25.9(2318)$ & $27.3(274)$ & $24(1086)$ & \\
\hline $1726-30$ & & & & $37(909)$ & & $25.3(665)$ & $26.9(500)$ & \\
\hline $1731-35$ & $22.7(382)$ & & & & $23(230)$ & $27.1(230)$ & $23.5(909)$ & \\
\hline $1736-40$ & & & & $33(543)$ & $34.4(1311)$ & $27(230)$ & $26(169)$ & \\
\hline $1741-45$ & $35.1(1153)$ & & $42.3(367)$ & $33.1(2155)$ & $22.7(958)$ & & $25.4(1285)$ & \\
\hline $1746-50$ & & & & $36.7(1050)$ & $36.5(438)$ & $21.9(230)$ & $20.5(196)$ & \\
\hline $1751-55$ & $35.2(522)$ & $33(185)$ & $33.9(570)$ & $35(4129)$ & $33(391)$ & $26.1(2171)$ & $34.7(2045)$ & \\
\hline $1756-60$ & $33.2(798)$ & $32(1069)$ & $38(840)$ & $39.6(1537)$ & $35.8(357)$ & $30.1(1724)$ & $28.8(3685)$ & \\
\hline $1761-65$ & $44.3(200)$ & $44.4(500)$ & $42.5(1118)$ & $39.3(1511)$ & $33.8(496)$ & $35.6(327)$ & $31(3030)$ & \\
\hline $1766-70$ & $37.8(138)$ & & $37.8(296)$ & $45.9(899)$ & $36.7(745)$ & $37.6(2752)$ & $44.5(2230)$ & \\
\hline $1771-75$ & $50.8(878)$ & $45.3(1220)$ & $48.2(374)$ & $47.5(4350)$ & $49.5(2568)$ & $42.7(5296)$ & $49.4(4403)$ & \\
\hline $1776-80$ & $45.3(280)$ & $41.8(1201)$ & $43.5(560)$ & $40(1267)$ & $45.4(1809)$ & $38(3579)$ & $53.8(429)$ & \\
\hline $1781-85$ & & $54.1(1263)$ & $45.4(392)$ & $55.4(792)$ & $55.6(1336)$ & 43(3034) & $66.2(5616)$ & $58.1(203)$ \\
\hline $1786-90$ & & $50(1586)$ & $51.8(2459)$ & $58.5(2742)$ & $67.5(1979)$ & $48(7515)$ & $77.4(5114)$ & $65.1(1244)$ \\
\hline $1791-95$ & $57.9(358)$ & $59.7(1695)$ & $66.3(437)$ & $65.7(2627)$ & $58(207)$ & $54.7(8193)$ & $63.7(2377)$ & \\
\hline $1796-1800$ & & & & & & $71.6(3843)$ & $72.5(697)$ & \\
\hline 1801-05 & & & & $75.3(230)$ & & $83(1707)$ & $67.5(1658)$ & \\
\hline $1806-10$ & & & & $77.9(1482)$ & $85.2(238)$ & $92.6(1052)$ & $75.6(508)$ & \\
\hline
\end{tabular}

\section{Entre parênteses a amostragem}

Fonte: David Eltis, Stephen D. Behrendt, David Richardson, e Herbert S. Klein, The Transatlantic Slave Trade: A Database on CD-ROM (Cambridge, 1999). 


\section{Apêndice 2 - Médias qüinqüenais dos preços em libras esterlinas de escravos masculinos (padrão da Jamaica), recém-desembarcados nas Américas em mercados selecionados, 1671-1810}

\begin{tabular}{|c|c|c|c|c|c|}
\hline & Carolina do Sul & Guianas & $\begin{array}{c}\text { Saint Domingue } \\
\text { /Jamaica }\end{array}$ & $\begin{array}{c}\text { Dominica/ } \\
\text { Granada/ } \\
\text { São Vicente }\end{array}$ & $\begin{array}{l}\text { Barbados/ } \\
\text { Antigua }\end{array}$ \\
\hline $1671-75$ & & & $25.0(1249)$ & & $19.3(1643)$ \\
\hline $1676-80$ & & & $19.9(4225)$ & & $17.1(5083)$ \\
\hline $1681-85$ & & & $17.6(3480)$ & & $16.1(3941)$ \\
\hline $1686-90$ & & & $19.8(4770)$ & & $17.8(3835)$ \\
\hline $1691-95$ & & & $19.8(2383)$ & & $21.5(3106)$ \\
\hline $1696-1700$ & & & $23(1163)$ & & $25.4(5321)$ \\
\hline $1701-5$ & & & $24(2724)$ & & $26(9377)$ \\
\hline $1706-10$ & & & $25.9(1727)$ & & $24.8(5639)$ \\
\hline $1711-15$ & $21(150)$ & & & & $26.1(315)$ \\
\hline $1716-20$ & & & $22.7(239)$ & & $18.3(232)$ \\
\hline $1721-25$ & & & $24(2290)$ & & $27.6(908)$ \\
\hline $1726-30$ & & & $30.3(1554)$ & & $27.8(924)$ \\
\hline $1731-35$ & $18.1(230)$ & $29.7(1653)$ & & & $23(230)$ \\
\hline $1736-40$ & & $23.3(777)$ & & & $24.5(1198)$ \\
\hline $1741-45$ & $35.1(1049)$ & $36.6(1618)$ & & & $35.1(1492)$ \\
\hline $1746-50$ & $31(1923)$ & $28(2447)$ & $37.1(230)$ & & $35.7(730)$ \\
\hline $1751-55$ & $43.1(2772)$ & $38.5(1279)$ & $32.6)(4040)$ & & $26.6(1422)$ \\
\hline $1756-60$ & $38.7(750)$ & $48(3024)$ & $36.7(4014)$ & & $29(681)$ \\
\hline $1761-65$ & $53(2428)$ & $43(2525)$ & $40.3(835)$ & & $30.8(98)$ \\
\hline $1766-70$ & & $44.1(1175)$ & $40.6(1154)$ & $39.1(2144)$ & $34.6(750)$ \\
\hline $1771-75$ & $58.5(790)$ & $51.5(145)$ & $49(6171)$ & $41.9(3574)$ & $43(1610)$ \\
\hline $1776-80$ & & $54.4(669)$ & $41(5536)$ & $35.6(1279)$ & $37.5(442)$ \\
\hline $1781-85$ & & $65.5(939)$ & $47(1168)$ & 42(1493) & $43.2(1067)$ \\
\hline $1786-90$ & & & $52.5(6917)$ & $48.2(5565)$ & $48.3(1300)$ \\
\hline $1791-95$ & & $63.6(230)$ & $59.7(959)$ & $53.2(1725)$ & $51.6(745)$ \\
\hline $1796-1800$ & $67.1(230)$ & $84.6(705)$ & $73(5596)$ & $66.5(460)$ & 64.3418 \\
\hline $1801-05$ & & & $78.7(2423)$ & $90.4(230)$ & \\
\hline $1806-10$ & & & $82.9(1865)$ & $90(460)$ & \\
\hline
\end{tabular}

Entre parênteses a amostragem

Fonte: David Eltis, Stephen D. Behrendt, David Richardson, e Herbert S. Klein, The Transatlantic Slave Trade: A Database on CD-ROM (Cambridge, 1999). 
Apêndice 3 - Regressão de preços de escravos homens recentemente chegados nas Américas, em libras esterlinas, padronizada para a Jamaica, por regiões de partida da África, qüinqüênios selecionados, 1676-1795 (o primeiro número na célula é coeficiente de beta, com t-estatística entre parênteses)

\begin{tabular}{|l|c|c|c|c|c|c|}
\hline & $1676-80$ & $1701-1705$ & $1751-1755$ & $1771-1775$ & $1786-1790$ & $1791-1795$ \\
\hline Alta Guiné & -3.107 & 2.25 & 8.17 & 5.22 & 2.71 & 5.8 \\
& $(-1.748)$ & $(0.6)$ & $(2.8)$ & $(2.3)$ & $(1.0)$ & $(1.6)$ \\
Costa do & .941 & 4.92 & 8.78 & 4.89 & 10.35 & 11.05 \\
Ouro & $(1.07)$ & $(1.8)$ & $(3.3)$ & $(2.5)$ & $(2.9)$ & $(2.8)$ \\
Baía de & -.278 & 3.54 & 6.84 & 6.85 & 19.36 & 3.31 \\
Benin & $(-0.302)$ & $(1.3)$ & $(1.0)$ & $(2.6)$ & $(4.7)$ & $(0.8)$ \\
Africa & -.745 & -2.92 & 8.62 & 6.7 & 29.28 & 8.99 \\
Central & $(-0.616)$ & $(0.4)$ & $(2.6)$ & $(3.1)$ & $(9.9)$ & $(2.3)$ \\
Attântica & & & & & & \\
Africa & & & & & 16.97 & \\
Oriental e & & & & & $(3.4)$ & \\
do Sul & & & & & & \\
Intercepte & 18.83 & 23.94 & 26.1 & 42.66 & 48.14 & 54.67 \\
& $(32.65)$ & $(9.91)$ & $(11.9)$ & $(33.4)$ & $(24.7)$ & $(28.1)$ \\
r2 & 0.121 & 0.18 & 0.22 & 0.15 & 0.58 & 0.16 \\
\hline
\end{tabular}

A variável de referência (intercepte) para cada equação é a Baía de Biafra Fonte: David Eltis, Stephen D. Behrendt, David Richardson, e Herbert S. Klein, The Transatlantic Slave Trade: A Database on CD-ROM (Cambridge, 1999). 
Apêndice 4 - Regressão de preços de escravos homens recentemente chegados nas Américas, em libras esterlinas, padronizada para a Jamaica, por regiões de chegada nas Américas, qüinqüênios selecionados, 16711795 (o primeiro número na célula é coeficiente de beta, com t-estatística entre parênteses)

\begin{tabular}{|l|c|c|c|c|c|c|c|c|c|}
\hline & $1671-$ & $1676-$ & $1681-$ & $1686-$ & $1691-$ & $1696-$ & $1701-$ & $1706-$ & $1741-$ \\
1675 & 1680 & 1685 & 1690 & 1695 & 1700 & 1705 & 1710 & 1745 \\
\hline $\begin{array}{l}\text { Carolina } \\
\text { do Sul }\end{array}$ & & & & & & & & & -16.97 \\
Guianas & & & & & & & & & $(-4.2)$ \\
Saint & & & & & & & & & -2.56 \\
Domingue & & & & & & & & & $(-2.6)$ \\
Dominica, & & & & & & & & & 3.36 \\
Sáo & & & & & & & & & $(1.5)$ \\
Vicente e & & & & & & & & & \\
Granada & & & & & & & & & \\
Barbados e & -4.53 & -1.8 & -0.56 & -1.10 & 1.75 & 2.34 & 1.67 & -1.1 & \\
Antigua & $(-3.1)$ & $(-2.7)$ & $(-0.95)$ & $(-1.16)$ & $(1.4)$ & $(1.5)$ & $(0.9)$ & $(-0.5)$ & \\
Intercepte & 25.0 & 19.83 & 17.57 & 19.81 & 19.79 & 23.08 & 24.35 & 25.94 & 35.1 \\
& $(20.1)$ & $(41.2)$ & $(41.7)$ & $(29.7)$ & $(19.9)$ & $(16.8)$ & $(14.6)$ & $(12.2)$ & $(22.8)$ \\
R2 & 0.44 & 0.14 & 0.02 & 0.04 & 0.08 & 0.08 & 0.02 & 0.01 & 0.69 \\
\hline
\end{tabular}

Fonte: David Eltis, Stephen D. Behrendt, David Richardson, e Herbert S. Klein, The Transatlantic Slave Trade: A Database on CD-ROM (Cambridge, 1999). 


\section{Apêndice 5 - Regressão da duração das viagens (em dias) de navios que aportavam na Jamaica e em Saint Domingue vindos de regiões da África, qüinqüênios selecionados, 1676-1795 (o primeiro número na célula é coeficiente beta, com t-estatístico entre parênteses)}

\begin{tabular}{|l|c|c|c|c|c|c|c|c|}
\hline & $1751-$ & $1756-$ & $1766-$ & $1771-$ & $1776-$ & $1781-$ & $1786-$ & $1791-$ \\
& 1755 & 1760 & 1770 & 1775 & 1780 & 1785 & 1790 & 1795 \\
\hline Carolina do & 2.47 & -5.74 & -1.88 & 3.93 & & 11.39 & & \\
Sul & $(1.0)$ & $(-2.8)$ & $(-0.4)$ & $(2.1)$ & & $(1.6)$ & & \\
Guianas & 3.98 & -8.74 & 7.41 & -6.06 & 3.13 & 4.38 & 1.85 & 5.76 \\
& $(1.46)$ & $-4.2)$ & $(2.34)$ & $(-3.2)$ & $(1.2)$ & $(0.4)$ & $(0.4)$ & $(1.0)$ \\
Saint & 2.77 & 8.9 & 11.36 & 4.4 & 9.23 & 18.4 & 21.35 & 3.38 \\
Domingue & $(0.6)$ & $(1.8)$ & $(2.4)$ & $(2.3)$ & $(3.4)$ & $(3.7)$ & $(11.4)$ & $(0.9)$ \\
Dominica, & & & -1.45 & -7.14 & -5.36 & -5.1 & -4.34 & -6.44 \\
São Vicente & & & $(-0.4)$ & $(-4.4)$ & $(-2.1)$ & $(-0.8)$ & $(-2.0)$ & $(-1.7)$ \\
e Granada & & & & & & & & \\
Barbados e & 6.01 & -7.7 & -5.94 & -6.67 & -3.46 & -3.9 & -4.26 & -8.1 \\
Antigua & $(-2.2)$ & $(-2.5)$ & $(-1.5)$ & $(-3.1)$ & $(-0.9)$ & $(-0.5)$ & $(-1.4)$ & $(-1.2)$ \\
Intercepte & 32.63 & 36.73 & 40.58 & 49.0 & 40.98 & 47.09 & 52.55 & 59.69 \\
R2 & $(23.0)$ & $(30.9)$ & $(15.0)$ & $(45.9)$ & $(36.5)$ & $(10.1)$ & $(36.0)$ & $(36.5)$ \\
& 0.22 & 0.22 & 0.43 & 0.44 & 0.41 & 0.55 & 0.70 & 0.10 \\
\hline
\end{tabular}

A variável de referência (intercepte) para cada equação é a Baía de Biafra Fonte: David Eltis, Stephen D. Behrendt, David Richardson, e Herbert S. Klein, The Transatlantic Slave Trade: A Database on CD-ROM (Cambridge, 1999).

\section{Notas}

${ }^{1}$ Laurence J. Kotlikoff, "Quantitative Description of the New Orleans Slave Market, 18041862," in Robert W. Fogel and Stanley L. Engerman (eds.), Without Consent or Contract: Markets and Production, Technical Papers 1:31-53; Katia M. de Queiróz Mattoso, To Be a Slave in Brazil, 1550-1888, traduzido do francês por Arthur Goldhammer (New Brunswick, 1986), págs. 55-81; Laird W. Bergad, Fe Iglesias García e María del Carmen Barcia, The Cuban Slave Market, 1790-1880 (Cambridge, 1995), 38-78; Laird W. Bergad, Slavery and the Demographic and Economic History of Minas Gerais, Brazil, 1720-1888 (Cambridge, 1999), págs. 163-87. Ver, particularmente, a tabela comparativa na p. 169 deste último.

${ }^{2}$ David Galenson, Traders, Planters and Slaves: Market Behavior in Early English America (Cambridge, 1986) 
${ }^{3}$ David Eltis, Stephen D. Behrendt, David Richardson, e Herbert S. Klein, The Transatlantic Slave Trade: A Database on CD-ROM (Cambridge, 1999).

${ }^{4}$ Richard Nelson Bean, The British Trans-Atlantic Slave Trade, 1650-1775 (New York, 1971).

${ }^{5}$ Coletados por Bergad, Iglesías García, and Barcia. Gostaríamos de agradecer a estes autores por nos terem disponibilizado seus dados.

${ }^{6}$ Preços convertidos para libras esterlinas de acordo com John J. McCusker, Money and Exchange Rates in Europe and America, 1600-1775: A Handbook (Chapel Hill, NC, 1978) e, para o período pós-1790, a séries "BW" na tabela de apêndice 1 de Lawrence H. Officer, "Dollar-Sterling Mint Parity and Exchange Rates, 1791-1834," Journal of Economic History, 43 (1983): 610-12, and Edward J. Perkins, "Foreign Interest Rates in American Financial Markets: A Revised Series of Dollar-Sterling Exchange Rates, 1835-1900," Journal of Economic History, 38 (1978): 410-12

${ }^{7}$ David W. Galenson, Traders, Planters and Slaves: Market Behavior in Early English America (Cambridge, 1986), cap. 3. Curiosamente, a prática normal no Brasil era oposta à vigente no Caribe britânico. Os comerciantes ofereciam os escravos menos desejáveis primeiro (Mattoso, To Be a Slave in Brazil, 55-59).

${ }^{8}$ Algumas informações sobre custos de transporte intercolonial são fornecidas por Richard Bean, The British Trans-Atlantic Slave Trade 1650-1775 (New York, 1975). Comerciantes coevos estavam cientes dos custos do transporte intercolonial, como o de Liverpool, Robert Bostock; Documentos de Bostock, Escritório de Registro de Liverpool.

${ }^{9}$ O Caribe ocidental era a quintessencial "área proibida”. Apesar da grande pirataria ter durado até a década de 1720, uma presença mais forte da marinha, associada com a guerra, reduziu sua incidência na década de 1690, e muito da atividade posterior aconteceu nas costas da África.

${ }^{10}$ Para justificar este procedimento ver David Eltis, "The Prices of Newly Arrived African Slaves in Cuba and Brazil, 1810-1867" (trabalho inédito, 1987).

${ }^{11}$ Isto significa que para os 12 anos a partir de 1763, e para a década depois de 1782, o número médio anual de pessoas trazidas através do Atlântico provavelmente não foi ultrapassado até a década de 1880 .

${ }^{12}$ A África Central Atlântica parece ser uma exceção a esta regra, mas na realidade fazia parte do padrão geral. Em primeiro lugar, os intervalos da tabela 2 anteriores a 1650 são de 50 anos ou ainda mais longos, ao passo que aqueles posteriores a 1650 são de somente 25 anos. Em segundo lugar, os dados referem-se somente ao comércio transatlântico. Os navios de escravos levaram escravos para portos no Velho Mundo em anos anteriores e mesmo os números sendo muito mais baixos do que viriam a ser durante o tráfico para as Américas, uma grande parte destas partidas provinha da África Central Atlântica.

${ }^{13}$ Considerando a divisão das Guianas entre franceses, holandeses e britânicos.

${ }^{14}$ Robert W. Fogel, Without Consent or Contract: The Rise and Fall of American Slavery (New York, 1989), págs. 18-21. 
${ }^{15}$ A série de Schumpeter-Gilboy é usada para períodos anteriores a 1808, e a série de Gayer, Rostow e Schwartz é usada para 1806 a 1850 e ajustada pelo índice de Rousseau de 1851 a 1865. Veja-se B. R. Mitchell, British Historical Statistics (Cambridge, 1988), págs. 719-22. ${ }^{16}$ Uma função cúbica em ambas as figuras.

Fig. 2 (a) é $\mathrm{P}=1497.5-1.41 \mathrm{Y}+0.000019 \mathrm{Y} 3 \mathrm{r} 2=0.66 \mathrm{~F}$ stat $=1042$

Fig. 2 (b) é $\mathrm{P}=-485.9+0.00009 \mathrm{Y} 3 \mathrm{r} 2=0.24 \mathrm{~F}$ stat $=302.8$

${ }^{17}$ Uma simples regressão de quadrados menores do volume de escravos em preços obtidos para antes de 1800

$\mathrm{Q}=-129,801+12,649.3 \mathrm{P}$

SE $\quad(32,765) \quad(1,167.3)$

t-stat (10.8) (4.0) r2=0.83

Para o período depois de 1800 , a equação era

$Q=568.9-4.246 P$

SE (173.6) (2.179)

t-stat (3.3) (1.95) r2=0.19

${ }^{18}$ De $£ 1.7$ milhão em 1700 a $£ 7.5$ em 1770 , e $£ 18.2$ milhão em 1850 . Para a derivação destas estimativas, veja Eltis, The Slave Economies of the Caribbean: Structure, Performance, Evolution and Significance," in UNESCO General History of the Caribbean, 5 vols. (Kingston, 1997-), 3, Franklin W. Knight (ed.), The Slave Societies of the Caribbean págs. 110-18. Para preços de açúcar e café ver Sheridan para o século dezoito, e Eltis, Economic Growth para o século dezenove. As regressões de séries temporais foram também aplicadas com base em uma variedade de características das viagem. Para tal análise foi possível usar os dados de viagens das base de dados de navios negreiros, em lugar das médias de cinco anos que foram necessárias para examinar os vínculos entre preços, quantidade de escravos e características de produtos. Nos perguntamos, na realidade, se o preço de escravos dependia da duração da viagem, do tamanho do navio - e até que ponto isso era refletido em dados de tonelagem, de número de escravos a bordo e de mortalidade a bordo. Só a tendência temporal foi altamente significativa nestas análises. A mortalidade a bordo era pouco significativa com um coeficiente negativo, sendo a mais provável explicação que aqueles sobreviventes de viagens com altas taxas de mortalidade provavelmente estavam em péssimo estado de saúde e, portanto, vendiam-se por menos. Porém, a inclusão de todas estas variáveis em uma equação gerou problemas de multicolinearidade.

${ }^{19}$ Para velocidade de embarcação em Bonny comparado a outros lugares da África Atlântica, ver Paul E. Lovejoy and David Richardson, “'This horrid hole': Commerce and Credit at Bonny 1690-1840', trabalho inédito.

${ }^{20}$ Embora não demonstrado na tabela 3, uma análise de 123 viagens para a Cuba após 1800 (não existia comércio de escravos para a Jamaica e Saint Domingue depois de 1807, e muito pouco originário da Costa de Ouro) não mostra diferenças significativas entre o Golfo de Benin, o Golfo de Biafra, e a África Central Atlântica. 
${ }^{21}$ Nossa conclusão é baseada somente em custos de envio e demanda de escravos. Ignora a influência possível de idéias dos senhores de plantations sobre a qualidade dos escravos recentemente importados e dos preços pagos por eles. Alguns historiadores têm chamado a atenção para a baixa estimativa para escravos vindos de algumas regiōes africanas (especialmente do Golfo de Biafra). Os diferenciais de preço por origem africana estão até certo ponto relacionados com as preferências conhecidas dos senhores, mas somos céticos sobre atribuir os diferenciais somente a fatores colaterais de demanda.

${ }^{22}$ Para uma revisão da literatura sobre este tópico e exame do assunto em partes diferentes das Américas vejam Russell Lohse, "Slave Trade Nomenclature and African Ethnicities in the Americas: Evidence from Early 18th-Century Costa Rica," 2001 (a ser publicado).

${ }^{23}$ Para alguma indicação da escala do movimento intercolonial de escravos veja David Richardson, The British Empire and the Atlantic Slave Trade', in P. J. Marshall (ed.), Oxford History of the British Empire: the Eighteenth Century (Oxford, 1998).

${ }^{24}$ David Richardson, 'The British Slave Trade to Colonial South Carolina', Slavery and Abolition, 12 (1991), págs. 133-4; Cornelis Ch. Goslinga, The Dutch in the Caribbean and in the Guianas 1680-1791 (Assen/Maastricht, 1985), págs. 315-16.Os dados de Goslinga também sugerem que a importação de escravos para o Suriname alcançou um pico em 1771 (pág. 423). É claro que um forte crescimento deu-se em ambas as áreas em períodos anteriores, mas somos ainda carentes de dados de preço para estes anos.

${ }^{25}$ David Geggus, "La Traite des esclaves aux Antilles françaises à la fin du 18me siècle: Quelques aspects du marché local," in Silvia Marzagalli and Hubert Bonin, (eds.), Négoce, Ports, et Océans, XVIe-XXe Siècles: Mélanges Offerts à Paul Butel (Bordeaux, 2000), pp. 235-245; idem, "The French Slave Trade: an Overview," William and Mary Quarterly, third series, LVIII (2001), p. 129. Permanece a possibilidade de que a definição empregada neste trabalho para escravos padrão — homens adultos vendidos no primeiro terço de duração do pregão de venda - não padroniza suficientemente o preço de escravos.

${ }^{26}$ Este parágrafo é baseado em David Eltis e David Richardson, "Productivity in the Transatlantic Slave Trade," Explorations in Economic History, 32 (1995): 465-84.

${ }^{27} \mathrm{O}$ momento no qual se deu a queda de preços na África variou de acordo com cada região, refletindo, entre outras coisas, a intensidade geográfica das atividade de repressão (Paul E. Lovejoy e David Richardson, "British Abolition and Its Impact on Slave Prices Along the Atlantic Coast of Africa, 1783-1850", Journal of Economic History, 551995 , págs. 98-120.)

${ }^{28}$ Barry Higman, Slave Populations of the British Caribbean, 1807-1834 (Baltimore, 1984), págs. 80-85. Para diferenciais de produtividade e de preços interilhas veja Stanley L. Engerman, "Economic Adjustments to Emancipation in the United States and the British West Indies," Journal of Interdisciplinary History, 13 (1982): 195-200.

${ }^{29}$ Stephen D. Behrendt, "Markets, Transaction Cycles, and Profits: Merchant Decision Making in the British Slave Trade," William and Mary Quarterly, 58 (2001): 171-204. Para um excelente microexame do relacionamento entre a oferta de escravos e a guerra na Costa do Ouro do século dezoito, ver Stephanie Ellen Smallwood, "Salt-Water Slaves: 
African Enslavement, Forced Migration, and Settlement in the Anglo-Atlantic World, 1660-1700," tese de PhD, Duke University, 1999, especialmente o capítulo 2.

${ }^{30}$ Para as mudanças culturais e sociais associadas com a ascensão da rede Aro e com o surgimento de Bonny, vejam os primeiros capítulos de G Ugo Nwokeji, “The Biafran Frontier: Trade, Slaves, and Aro Society, c. 1750-1905” (Tese de PhD inédita, University of Toronto, 1999). Nwokeji aponta "um olhar sobre fatos sociais tais como o casamento e a proibição de incesto imediatamente revelam como estes estavam fortemente enlaçados com a escravidão. O sistema de crenças e deidades eram baseados e reforçados por processos relacionados à escravidão. $\mathrm{O}$ sistema de valores celebrava a propriedade e a proliferação das pessoas, e encorajava a venda de outros para a escravidão no Atlântico. A decisão relativa a quem enviar para o cativeiro no Atlântico e quem reter era central para a economia política Aro..."

31 “Considerações sobre espanhóis comprando negros da firma inglesa English Ro'll Company e recebendo 2/3 da compra na Jamaica e 1/3 em Barbados” Jamaica, 2 de fevereiro de 1675, Egerton ms, British Library Add ms, 2395, f 501. Também em CO31/1, ff. 6-7.

${ }^{32}$ Os feitores da Jamaica disseram ao RAC em dezembro, 1690 que a guerra os impediu de honrar as condições do contrato de Asiento do ano anterior. (Penhallow e Ruding para RAC, 9 de dezembro de 1690, T70/57, F. 55.) Pouco mais de um ano mais tarde o feitor escreveu que "o Asiento nas mãos de Nicholas Porcio e do Sr James Castell está confirmado por mais cinco anos e Grandes Ofertas de Negros são trazidas para eles pelos holandeses." (Walter Ruding para RAC, 2 de fevereiro de 1692, T70/17, F. 51). Em 1694 o feitor escrevia "Não posso encorajar o envio de negros. O Assentista está morto... e não se sabe o que fazer com os Negros" (idem, 14 de fevereiro de 1694, ibid). No ano seguinte, "A menos que o Assiento seja Estabelecido, pouca Prata ou Ouro pode ser Esperado." (Chas Whittall, 95.08.22. T70/12, p.151). Para os efeitos dos ataques franceses, veja Beeston, Barnard, Whittell para o RAC, 28 de julho de 1693, T70/12, F. 94; 21 de junho de 1694, ibid, F. 96; 12 de dezembro de 1694, ibid.

${ }^{33}$ A seção norte de Saint Domingue, dominada pelo açúcar, era onde preços mais altos eram pagos. Devemos também notar que enquanto os preços de escravos no sul dos EUA excediam os praticados em Cuba desde 1830 até o final da década de 1840, existia também alguma feição de barreira protetora entre estes dois mercados, na forma de uma proibição extremamente efetiva do comércio de escravos africano para os EUA.

${ }^{34}$ Por algumas décadas em meados do século dezesseis uma economia secundária de exportação de açúcar florescia nas Antilhas espanholas. Depois disso, com os portugueses concentrando-se no Brasil e os espanhóis no continente, os três lugares-fortes espanhóis nas Antilhas - Cuba, Hispaniola e Porto Rico - se tornaram povoados estratégicos protegendo rotas de comércio, os quais produziam também alguns artigos de exportação que não eram de plantação em grande escala. Para o diferencial de preços de escravo entre Jamaica e Cuba na primeira metade do século dezoito, veja Colin A. Palmer, Human Cargoes: The British Slave Trade to Spanish America, 1700-1739(Urbana, 1981), pp. 123124. O sistema espanhol de posse de terras coloniais foi também muito importante para 
o retardamento do desenvolvimento. Veja Manuel Moreno Fraginals, The Sugarmill: Socioeconomic Complex of Sugar in Cuba (New York, 1976) págs. 20-25.

${ }^{35}$ Veja E.W. Evans e David Richardson, Hunting for Rents: The Economics of Slaving in Pre-Colonial Africa, Economic History Review, 48 (1995), págs. 665-86.

${ }^{36}$ Eltis, Economic Growth. Para o caso do Senegal ver Michael Kielstra, The Politics of Slave Trade Suppression in Britain and France, 1814-48: Diplomacy, Morality and Economics (Basingstoke, 2000), págs. 93-148.

\section{Resumo}

$O$ presente artigo analisa as flutuaçôes dos preços dos escravos recém-desembarcados nas Américas, com ênfase especial para as colônias britânicas do Caribe e para os Estados Unidos. Parte-se do suposto de que os preços podem ajudar a determinar aspectos cruciais da história do tráfico negreiro, tais como a interconexão entre os mercados $e$ as determinaçôes estruturais da oferta e da demanda. Seu material empírico provém de uma base de dados publicada pela Cambridge University Press, em 1999.

\section{Abstract}

This article analyzes the fluctuations of the prices of slaves new arrived in America, specially in the british Caribean colonies and in the United States. The analysis supposes that the study of the prices is helpful in order to determinate main aspects of the black slaves trade history, as well as the connexions between markets and the structural determination of offer and demand. The empirical support of the study comes from a database published by Cambridge University Press, in 1999. 